\title{
4. A Matter of Form
}

\begin{abstract}
The previous chapters show that Bazin was never keen on all-inclusive formulas for studying film; this chapter illustrates that he even found himself occasionally either defending his opponents or reconsidering his own arguments. I elaborate on the relationship between form and content, with a specific emphasis on advertisement and poetry, which is crucial to understanding Bazin's methodology. This discourse in fact exceeds Bazin's context: it surfaces decades later in the work of Serge Daney and returns today in discussions on 3-D (and even to a certain extent, Virtual Reality). The analyses in this chapter follow Bazin's lineage and should show that his critical work stands the test of time and the tide of evolution of film.
\end{abstract}

Keywords: form and content, film analysis, 3-D, Virtual Reality

To refuse the evolution of techniques is to condemn civilization to a static life; it is to refuse to be modern; that is, to refuse to be at all.

André Bazin, 1953d

To this day, Bazin's film criticism has been associated almost exclusively with realism. Yet there were times that he had to defend the exact opposite position. In 1948, when he wrote some of his best pieces on depth of field in William Wyler, ${ }^{1}$ for example, he was accused quite strongly of being a 'formalist', and from the debate that followed we can see a much more nuanced but nevertheless fierce Bazin. The most direct accusation was made by Georges Sadoul, who argued that Bazin and his colleagues at Écran français 'attach more importance to form than to content'. ${ }^{2}$ The nuances

1 A concise but clear overview of the debates following 'William Wyler, or the Jansenist of the Mise en scene' (1948) between Bazin and Sadoul has been published under the title 'Convergences et divergences sur la profondeur de champ et le sujet' (1895: Revue d'histoire du cinéma, No. 67, Summer 2012: pp. 126-143), comprising excerpts of six texts that clarify the discussion from both sides.

2 Sadoul, 1948, p. 135 .

Joret, B., Studying Film with André Bazin, Amsterdam: Amsterdam University Press, 2019 DOI: $10.5117 / 97894629895^{28 / \mathrm{CHO}} 4$ 
Bazin provides in his responses are indicative of the ways in which Sadoul's claims caused him to rethink the realist and the formalist discourse. Here, for example, he writes:

Since two or three years, a quarrel divides cinematographic critique. It is true that it might seem as nothing but the shadow of a great dispute between realism and formalism in art [...]. Nevertheless, I think that the problem of formalism arises very differently in cinema and in most of the arts. ${ }^{3}$

Even though these comments were raised in a specific historical context, this assertion in fact summarizes Bazin's view on the evolution of cinematographic language, which inevitably leads to current matters in film theory. Bazin's criticism generally oscillates from a 'realist' defence of sound cinema, discussed in the first chapter of this book, to a 'formalist' treatment of depth of field, which I will analyze from the perspective of contemporary criticism of three-dimensional cinema.

In the following pages, I focus on Bazin's particular defence of 'realist formalism', which is how I understand his notion of 'integral realism': the achievement of increased realism inherent in the evolution of forms. In a similar vein, Jon Wagner reads in Bazin's myth of total cinema 'a realism formalist in its formation'. ${ }^{4}$ He puts it very convincingly:

Integral realism; a recreation of the world unburdened by the irreversibility of time; myth: when Bazin describes the genesis of cinema in terms of his realist ideal, and when this ideal entails illusory representation and temporal recreation, I think he comes close to defining his own formalism. ${ }^{5}$

The previous chapters have shown that Bazin was never keen on all-inclusive formulas for studying film; this chapter illustrates that he even found himself occasionally either defending his opponents or reconsidering his own arguments. In fact, as I will argue, the quarrel between form and content exceeds Bazin's context: it surfaces decades later in Serge Daney's famed critique of the popular feature film The Big Blue (Luc Besson, 1988) in terms of 'amnesic, aphasic images' without content, and returns today in discussions on $3-\mathrm{D}$ (and even to a certain extent Virtual Reality). The analyses in this chapter 
follow Bazin's lineage and should show that his critical work stands the test of time and the tide of evolution of film.

\subsection{Form + Content}

The first chapter of this book on Bazin's critical methodology ended with a section on his mayonnaise theory: a quarrel with Truffaut on auteur theory. In it, I have already raised the importance for Bazin of form and content: as much as he rejects the artificial distinction between the author and his work, he also rejects 'the distinction one learned at school between form and content'. ${ }^{6}$ By now, it's clear that Bazin's teaching, through debates at the ciné-clubs and in his writing, was different from traditional school or university systems. In a preface to Bazin's biography, a eulogy titled 'We Miss André Bazin' (1977), Truffaut reformulates the auteur theory formula in favour of Bazin into a 'politique des auteurs-critiques': 'one negative review by Bazin described the film better than an eloquent article by any of us. ${ }^{7}$ For Bazin, being a film critic was 'more than a job [...] it was a pleasure that he felt, a pleasure and a necessity linked to his educational calling. ${ }^{8}$ Truffaut's text is centered on one particular image related to Bazin's flexibility of thought and characteristic of his educational calling: aquarium light.

In 1948, Bazin wrote an article on Jean Renoir's The Diary of a Chambermaid, a film Renoir made during his Hollywood years in the late forties. Bazin then wrote, dismissively, in Écran français, that the sunshine on the roses of Burgess Meredith made 'this entire film bathe in that aquarium light, characteristic of the Hollywood studios'. ${ }^{9}$ Several years later, he changed his mind and described this experience as follows:

I in fact had a painful impression during the first minutes of the projection, the time to finally understand my mistake and how absurd it was to persist in wanting to see a lack of realism in the most dreamlike film and the most deliberately imaginary film in Renoir's oeuvre. [...] About this aquarium light that shocked me so much before, of course again I found it, but it appeared to me as the light coming from the earth. ${ }^{10}$

6 Bazin, 1957b, EC p. 2154; Transl. Graham, 2005, p. 255.

7 Truffaut, 1983 , p. 57 .

8 Ibid., p. 55 .

9 Bazin, 1956c, EC p. 2004.

10 Ibid., EC p. 2005. 
This is in 1956, about a decade later, and Bazin admits he had had back then a prejudice which, as the title of the essay reads, 'cost him dearly'. According to Truffaut, "this "aquarium light" is an important find, it puts the emphasis on the most startling contrast of post-war cinema: the forms of Hollywood and neo-realism'." Aquarium light technically refers to a specific lighting technique typical of Hollywood studios but also adopted by the New Wave film directors. It involved projecting light towards the ceiling of an interior, which created a uniformly lit space without shadows. In Nestor Almendros' words: 'Unlike before, looking like it was carved out, the light invades everything almost evenly, as an aquarium light. ${ }^{\prime 2}$ Itself a poetic image, this aquarium light shows a two-sided Bazin: realism in 1948, and formalism almost a decade later. When we read his work today, then, we find two seemingly opposing strands combined. Highlighting the same binary in Bazin's work, Dudley Andrew writes:

Bazin affirmed that in the cinema 'poetry' and 'realism' were congenitally conjugated, that there was no way of speaking of realism without poetry and conversely that no film or technique could approach the poetic without a degree of realism. ${ }^{13}$

By acknowledging two sides of the coin, Bazin's body of work displays a flexibility unlike any comprehensive study of film. Truffaut indeed does not describe Bazin's second thoughts about Renoir as an apology or a guilty confession; instead, aquarium light is 'an enthusiast and stimulating deepening' of his criticism, which he qualifies as 'in-depth criticism'. ${ }^{14}$ Beyond a simple expression of regret, Bazin acknowledged that prejudice illuminates a particular semantic process in his work centered on the poetic use of forms.

\subsubsection{From Advertising to Poetry in Bazin}

The title of the particular essay in which Bazin points to his own misconception, 'A Prejudice that Cost Me Dearly' [Un préjugé qui me coûtait cher],

11 Truffaut, 1983, p. 57.

12 Almendros, 1990, p. 14; The Spanish cinematographer Nestor Almendros (1930-1992), working with Eric Rohmer as well as with Truffaut among many others, used this lighting technique abundantly. With aquarium light, the set is illuminated from below (with the lights themselves carefully placed out of frame, of course), towards the ceiling; this created indirect, diffuse light. It eliminated shadows, uniformly lighting up the space much like an aquarium. This technique was used in Italian neo-realism, Nouvelle Vague films as well as in the Hollywood studios.

13 Andrew, 1995, p. ix.

14 Truffaut, 1983, p. 57; Truffaut here recalls Bazin's own aspirations from 1942. 
refers to a French advertisement slogan for a margarine brand Astra, widely disseminated during the fifties (Fig. 30). Competing with real butter, Astra needed to tilt the French towards buying cheaper margarine - a difficult endeavour in post-war France: why go for the cheaper alternative now the war was over? As a rhetorical tactic, the brand developed a campaign entirely based on refuting prejudice by staging everyday culinary habits, much like the script of a theater or film scene. During the same time, and with the exact same advertisement in mind, the semiotician Roland Barthes (1915-1980) describes this strategy as an 'immunization' of the people: Astra used 'a narrative pattern which clearly shows the working of this new vaccine'. ${ }^{15}$ Published in 1957, his Mythologies would become foundational for visual semiotics and discourse analysis: from a structuralist point of view, Barthes argued that messages coded within a certain discourse, such as advertising, contain certain signs (an image, a dialogue) that signify or connote something beyond their apparent denotation. This sentence, 'a prejudice that cost me dearly', does not signify that some French housewife changes her mind about margarine, but is instead designed to sell a product. Taking the infamous line in a different direction, Bazin's title turns it into a methodological inquiry: in criticism, what could be the role of prejudice, second thoughts or, to stick with food preferences: personal taste? In his own text on auteur theory, Bazin indeed affirms the necessity of taste in criticism:

I feel there are two symmetrical heresies, which are (a) objectively applying to a film a critical all-purpose yardstick, and (b) considering it sufficient simply to state one's pleasure or disgust. The first denies the role of taste, the second presupposes the superiority of the critic's taste over that of the author. Coldness ... or presumption! ${ }^{16}$

Personal taste, in itself a kind of prejudice, has its place in film criticism; yet, so Bazin argues, it should never overrule the taste or style of the filmmaker. The fact that Bazin concerns himself with advertising in the title is important and offers a slightly different signifying process by using the most powerful yet least meaningful form as a methodological inquiry.

From a semantic point of view, Bazin's reference to the Astra advertisement should be seen as poetic: ${ }^{17}$ as the poets do with language, he takes

15 Barthes, 1957, p. 42.

16 Bazin, 1957b, EC p. 2154; Transl. Graham, 2005, p. 256.

17 This line in particular has indeed been used by the writer Georges Perec (1936-1982), who includes it in his memories from 1946-1961 in Les choses communes: Je me souviens (1978): 'Je 


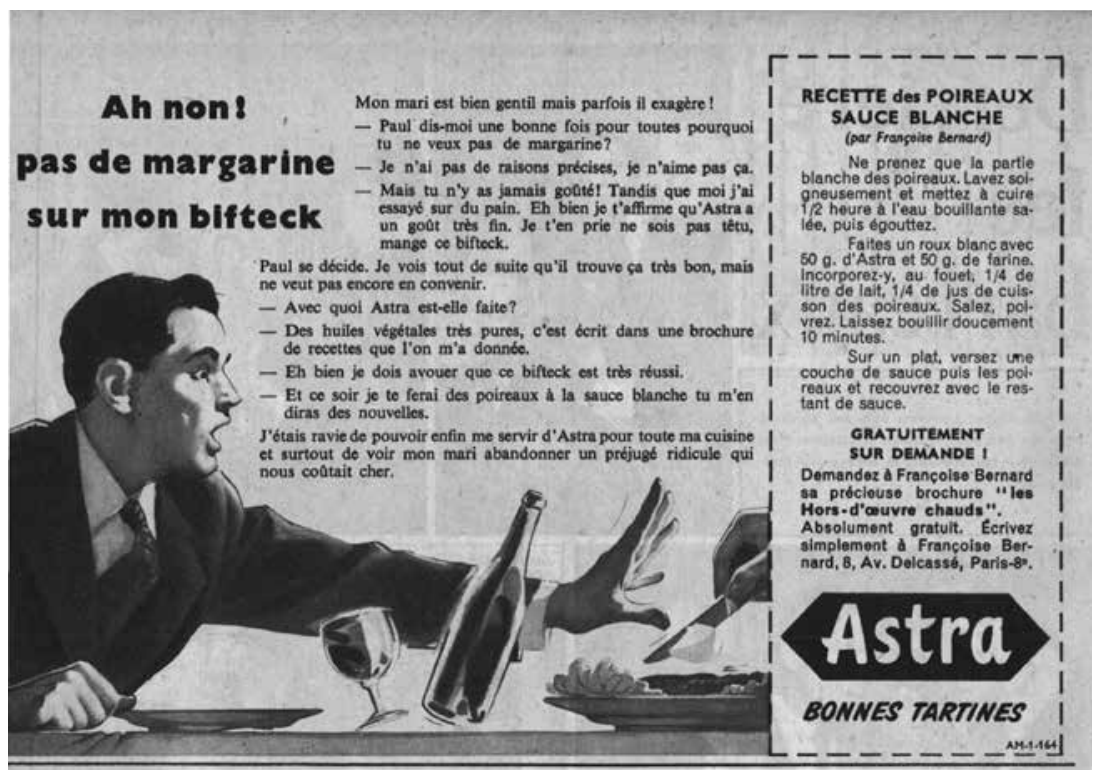

Fig. 29 Form: A prejudice that cost me dearly

an existing sentence with its own form, sound or rhythm and then fills it up with new content. Before turning to the notion of advertising images linked with the form and content debate, crucial in order to fully grasp the formalist traits in Bazin's methods as well as his relevance in more contemporary media contexts, let me first explain this poetic use of language in his work. On numerous occasions, poetry is used to frame and explain central concepts in Bazin's work: for example, Stéphane Mallarmé's famed final phrase illuminates in Bazin 'the maxim of ontological realism at its purest reformulation of classical mimesis. ${ }^{18}$ A lesser-known case of poetry in Bazin's texts is the essay mentioned previously on the underwater documentary film, The Silent World (Jacques-Yves Cousteau and Louis Malle, 1956). In it, Bazin writes:

La mer scintillante de lumière n'était au poète méditerranéen qu'un toit tranquille où marchent les colombes, celui des focs et non des phoques.

me souviens... Astra, un préjugé qui vous coûtait cher' (Perec, 1978, p. 39). With his frequent wordplays, crosswords, or univocalisms, among other experiments in language, Perec is known for his innovative use of form.

18 Joubert-Laurencin, 2014, p. 49; pp. 153-158. 
[The sea shimmering with light was to the Mediterranean poet but a tranquil roof where the doves walked by, the roof of the jibs and not the seals. $]^{19}$

The Mediterranean poet Bazin refers to is Paul Valéry (1871-1945). A symbolist poet like Mallarmé, he seeks meaning beyond appearances in nature: put bluntly, a tranquil sea symbolizes death, or a breeze symbolizes hope. Bazin's choice of words in his critique of The Silent World indeed betrays a recurring preoccupation with this particular poem, titled The Seaside Cemetery (1920). Consider its very first and last sentence: ${ }^{20}$

$\begin{array}{ll}\begin{array}{l}\text { Ce toit tranquille, où marchent des } \\ \text { colombes, }\end{array} & \begin{array}{l}\text { This quiet roof, where dove-sails } \\ \text { saunter by, }\end{array} \\ {\left[\begin{array}{l}{[. .]} \\ \text { Ce toit tranquille où picoraient }\end{array}\right.} & {[\ldots]} \\ \text { des focs! } & \text { This quiet roof where sails like doves } \\ \text { were pecking. }\end{array}$

From beginning to end, Bazin incorporates Valéry's symmetries pertaining to water and air: wings (les colombes) and feet (marchent), sails (des focs) and fins (et non des phoques). Following the rhythmic organization of this poem, the essays on The Silent World ultimately bring about a reformulation of the critical categories of form and content. Through homonym, Bazin suggest that the sea can symbolize either a superficial, shiny surface (le toit des focs) or a three-dimensional body (celui des phoques): 'the space below, which is the space of life. ${ }^{21}$ On several occasions, Bazin in fact mentions this particular poem, always in defence of a certain degree of formalism:

If nature proceeds from the inside to the outside, from cause to effect, it is the privilege of art, as of science, to induce matter or to deduce form. Paul Valéry built The Seaside Cemetery upon the cadence of a single line of verse. ${ }^{22}$

And so Bazin's article on Cousteau is in turn built on a poem that was written from 'an obsession with a certain rhythmic frame, initially empty, which Valéry then fills little by little with content that he thought was freely 
chosen'. ${ }^{23}$ More specifically, in his interpretation of Cousteau's underwater exploration, Bazin reformulates Valéry's vision of the surface of the ocean as the roof of an unexplored part of the universe, and thereby moves beyond symbolism: there is depth underneath the surface. By converting Valéry's The Seaside Cemetery, Bazin thus ultimately claims his invested interest in recreation as an affirmation of trans-forming the world in its image, or a text in a text, or indeed film into criticism.

Where Bazin's oft-cited reference to Mallarmé relates to the process of recreation in realism, the reference to Valéry applies recreation to methodology and film criticism. With this discourse in mind, Truffaut's description of criticism being 'in-depth' is equally important. From a physiological perspective, depth perception depends on binocular vision; likewise, aquarium light in Bazin defies one-sighted, superficial criticism. In Bazin's words, from 1943: 'One would say that this particular art has no past, no thickness, like those ephemeral shadows on a screen. It's high time to invent three-dimensional film criticism. ${ }^{24}$ Taking into consideration that shadow plays are pre-cinematic practices, Bazin's call for three-dimensional criticism is, ultimately, a call for criticism sensitive to the evolution of forms which, I argue throughout the following pages, logically culminates in his essays on 3-D cinema.

\subsubsection{Depth, Water and the Evolution of Forms}

Rather than favoring content over form, it is as a realist that Bazin rejects the distinction traditionally made in art criticism. Building on the Newtonian framework discussed previously to explain Bazin's radical approach to realism as no more and no less than reality, I now add a corollary to this: form and content are in his view ultimately equal. Already in the ontology essay, he writes that, ultimately, 'every image should be experienced as an object and every object as an image.' ${ }^{25}$ It is, furthermore, in semiotic terms that he envisions this equilibrium from a film critical point of view:

[...] every technique is completely responsible for what it expresses, or every form is a sign, and where nothing is really said without its being couched in the necessary form. Criticism could then be practiced, at least on the best films, as it has been practiced now for a century on the best literature, beyond [au-delà] the otherwise artificial categories of 
form and content. Nevertheless, I would like to point out that 'content' and 'form' in cinema are not always what a biased or superficial analysis might assume. This is the reason why criticism cannot remain indifferent. It must discern from vain technical acrobatics the artistic imagination, which enables cinema to go deeper and further. ${ }^{26}$

Bazin's desire for tradition, to move from the ephemeral shadows towards 3 -D, is clearly tangible in this passage. In 'The Myth of Total Cinema', he initially defends the talking film as an imperative stage in the development toward integral realism: techniques such as sound, color and ultimately relief all contribute to an increased realism, 'the recreation of the world in its own image'27 - the ultimate, aspired equality between object and image. Yet recreation, I have just argued, also functions in his film critical work: to use Truffaut's formulation, when Bazin discusses aquarium light he is at his best, 'like a fish in the water'. ${ }^{28}$

To grasp the full meaning of this in-depth methodology, another scientific reference in Bazin needs elaboration: Archimedes' principle of buoyancy, which states that 'any solid lighter than a fluid will, if placed in the fluid, be so far immersed that the weight of the solid will be equal to the weight of the fluid displaced.. ${ }^{29}$ Alongside his Newtonian framework, Bazin writes about Cousteau's underwater film:

The only thing needed was, first, to be freed from this reversed gravity which is Archimedes' principle; then, to be given ambient pressure by the pressure modifier to not end up in the fleeting and dangerous situation of a diver, but in that of Neptune, master and inhabitant of water. Finally, man flies with his arms! ${ }^{30}$

Bazin makes it very clear that the water in The Silent World is threedimensional: 'It is not anymore about a symbolism attached to superficial, mobile, streaming, lustral water, but rather about the Ocean: a three-dimensional milieu, more stable, moreover, than air and in which submergence frees us from gravity. ${ }^{31}$ In water, several things can happen: you can swim, drift, dive, or drown - but Bazin now seems more interested

28 Truffaut, 1983 p. 59 .

29 Archimedes, 1897, p. 257.

30 Bazin, 1956c, EC p. 1915.

$3^{1}$ Ibid. 
in the experience of weight, or volume, rather than weightlessness. Under water, mass does not prevent flight but instead, thanks to the buoyancy principle, enables it. Eureka! Finally, man flies with his arms: 'the fish becomes bird. ${ }^{32}$

Water, especially in relation to its reservoir, indeed articulates Bazin's particular views on the evolution of film language - and, in effect, perhaps because of its fluid, formless state, it permeates the larger debate on film form after Bazin. Arguing against Bazin's supposed formalist turn, Sadoul wrote: 'To lose sight of the subjects ends up in classifying films according to their technology $[. .$.$] which is like thinking that the vintage of a wine is determined$ by the form of the bottle, of a Champagne, Bordeaux or Bourgogne. ${ }^{33}$ All the while pursuing the analogy with fluids, Bazin replies to this that: 'The relationship between form and matter is not that of container and contents, of bottle to liquid, but more that of shell to clam. ${ }^{34} \mathrm{He}$ further develops the maritime reference to a symbiotic existence into his famed metaphor of the 'equilibrium profile of a river flow', by which he explains the evolution of film language:

Once it has reached its equilibrium profile, a river flows effortlessly from its source to its mouth without further eroding its bed. But should any geological movement occur to raise the peneplain and modify the height of its source, the river's water sets to work again, penetrating the ground underneath it, eating away at, boring and breaking through it. Sometimes it encounters limestone and hollows out a new and almost invisible course across the tableland, a course whose flow of water is twisted and complex. ${ }^{35}$

The course of a river is determined by processes of erosion, transportation and deposition, which make it impossible to dissociate the water flow from its bed. Similarly, without its container, water has no form: technological inventions, social situations as well as political contexts, for example, shape the evolution of film language - and without water the container loses its purpose: the image becomes no more than an empty signifier.

32 Bazin, 1956f, EC p. 1968.

33 Sadoul, 1948, p. 135; As a side-note, it is perhaps worth pointing out that Sadoul's example is ill-founded: all these wines, in fact, develop their particular qualities in relation to the shape of their bottles.

34 Bazin, 1951e, EC p. 686; Transl. Cardullo, 2014, p. 17.

35 Bazin, 1950-1955, EC p. 978; Transl. Barnard, 2009, p. 96. 
Bazin's entire discourse on recreation is built around change and evolution in film form, theory and criticism. As such, it initiates a strong lineage in French film criticism specifically relating to water, depth and surface in terms of meaning and form. Continuing this tradition, Bazin's most prominent successor Serge Daney (1944-1992) introduces a generational revolution in French film criticism: a radical 'return to cinema' in the eighties, following the structuralist and semiotic orientation in the sixties, ${ }^{36}$ echoes Bazin's call for the existence of film as the critic's point of reference. Facing the 'defeat of (film) critical thinking', Daney emphasizes the need for a cinephile tradition:

[...] cinema has a completely original connection to filiation and when this connection ceases to exist, like today, cinema risks to cease as well, finding itself replaced overnight by images of another country, by a genetically produced visual.

Loving cinema is loving this idea that we always make do with bodies that have already served, that have existed for others. ${ }^{37}$

The bodies Daney refers to are both realist (cinema borrows existing forms from reality, which it transforms) as well as formalist (cinephilia necessitates knowledge or usage of existing artistic forms). Surprisingly (or not), it is to water that Daney takes in his melancholic essay on post-modern film culture, titled 'Cinema and the Memory of Water' (1989). In what follows, I focus on his critique of Luc Besson's popular feature film The Big Blue (1988), which stirred the critical discourse with highly aestheticized imagery. In many ways, Daney's work on Besson puts recreation to work as a critical method: as Joubert-Laurencin writes on the topic of Besson's underwater documentary Atlantis (1991), 'through Daney, Luc Besson has seen Bazin'. ${ }^{8}$ More specifically, I maintain that Daney's film criticism implicitly builds on Bazin's discourse, which speaks of shadows and bodies as well as tradition through recreation, and extends its validity into an entirely different media context.

\subsubsection{On Floating Bodies: Serge Daney and the Case of Le Grand Bleu}

Roughly thirty years after Bazin, Daney's film culture is at first sight far removed from neo-realist and nouvelle vague stylistics. The cinema of 
Besson, characteristic of the so-called cinéma du $l o o k^{39}$ of the eighties, displays an advertising, glossy magazine aesthetic: stereotypical, cliché-like imagery with vibrant colors, soothing soundtracks and an impeccable mise-en-scène dominate a more authentic depiction of reality. The question that drives Daney's discourse is still, however, an ontological one:

The filmed cinema, that of Besson, inherits 'forms' but no 'bodies' (Platonic, not Aristotelian). These forms, which are rather derisory, are nevertheless the only existing memory (genetic memory of cinema) and the only truth. [...] What is needed are bodies that correspond to the publicity advertising world that surrounds us. [emphasis in original ${ }^{40}$

These forms without body, Daney continues, are 'amnesiac images', images with memory loss: 'when I see The Big Blue, I don't see the sea, I see an advertising concept of the sea that has once and for all replaced the sea. ${ }^{41}$ In short, Daney sees Besson's blue movie as emblematic of a collective aphasia: "The famous "crisis of scenarios", which bores our ears, it is there: in the privatization of experience and the aphasia it produces, especially among the youth. ${ }^{42}$ When form takes over content, nothing is left to say, nothing is being exchanged: collective apathy reflected in a lack of dialogue.

Indeed, in The Big Blue everything is set for a romance that never unfolds: a once-in-a-lifetime chance meeting somewhere in the Peruvian middle of nowhere, the subsequent man-hunt that leads a woman, Joanna, from New York all the way to the Mediterranean coast, where finally she reunites with her love at first sight. But this man, Jacques Mayol, is only interested in diving, even when Johanna turns out to be pregnant; even when his best friend Enzo has died, running after the same obsession with depth. 'To hold your breath, to stop breathing', ${ }^{43}$ as Daney puts it, is characteristic of free-diving as well as Besson's film aesthetics. In fact, the only time when Jacques explains his apathy towards life on dry land, he reinforces again his aphasia: 'you have to find a good reason to come back up, and I have a hard time finding one.' Ultimately, the highly aestheticized, smooth forms of The Big Blue tell the story of suicide. Jacques chooses to be with the mermaids:

39 The term cinéma du look was first coined by the critic Raphaël Bassan in 1989, applicable to Besson's films as well as those from Leos Carax and Jean-Jacques Beineix. On this topic, see Austin, 1996, pp. 119-134.

40 Daney, 1993, p. 238.

41 Ibid., p. 293.

42 Ibid.

43 Daney, 1989, p. 164. 
Do you know how it is; do you know what you're supposed to do to meet a mermaid? You go down to the bottom of the sea, where the water isn't even blue anymore, where the sky is only a memory. And you float there, in silence, and you stay there and you decide that you'll die for them. Only then do they start coming out. They come, and they greet you and they judge the love you have for them. If it's sincere, if it's pure, they'll be with you and take you away forever.

Beyond aesthetics, then, Daney's critique is indeed political: the film's immense popularity at the time pushed an entire generation of copycats, nicknamed les allumés du Grand Bleu, to engage in deep-sea diving (often to death). ${ }^{44}$ It is not a shark this time but dolphins and mermaids where authenticity is sought after. Thus, in The Big Blue, Besson provides another discourse on the connection between authenticity and death, and he does so via a certain 'pure' formalism traditionally emptied of authenticity: from the point of view of Narcissistic superficiality rather than Icarian audacity.

Platonic forms as opposed to Aristotelian bodies: in Daney's work as well as in Bazin's, these references are in fact crucial to understand the interrelation between content and form. For example, in his 'Myth' essay Bazin speaks of an ideal cinema descending from its platonic heaven, just as airplanes have realized the Icarus myth (human flight). He then picks up the Icarus myth again in his review of Cousteau's documentary, to argue for an Aristotelian cinema: thanks to buoyancy, Icarus swims/flies with his arms. In this manner, the discourse surrounding Besson's highly aestheticized imagery inevitably brings us back to Bazin, more specifically to the notion of water discussed earlier in this chapter. In The Big Blue, shiny surfaces, the sunlit ocean and wet, dolphin-like bodysuits are the dreamy clichés that altogether constitute this 'symbolism attached to superficial, mobile, streaming, lustral water', 45 to which Bazin opposes The World of Silence as a return to origins:

[the images] are the accomplishment of an entire mythology of water, of which the material fulfilment by these subaquatic supermen encounters within ourselves secret, profound and age-old connivances. ${ }^{46}$

44 Claude Chapuis, cited in 'Tout le mal que "Le Grand Bleu” a fait à l'apnée.' 20 minutes, 02/06/2016 [Accessed 30/10/2017] <http://www.2ominutes.fr/marseille/1857651-201606o2-toutmal-grand-bleu-fait-apnee>. After receiving an account of irresponsible free-diving in Lake Titicaca, copying an enigmatic scene from the film, Chapuis - himself world champion in 1990 - founded the AIDA (or the International Foundation for the Development of Free-diving).

45 Bazin, 1956c, EC p. 1914.

46 Ibid. 
It is precisely the lack of the latter, the three-dimensional ocean, that portrays The Big Blue as nostalgia for reality: a bit of a blue movie about having the blues. ${ }^{47}$

Similarly, many films set in or around swimming pools find themselves at the crux of imagination, memory loss, superficiality, and nostalgia. Exemplary of luxury and wealth, swimming pools are the ultimate advertisement settings where image takes the upper hand over reality. In The Graduate (Mike Nichols, 1967), the swimming pool offers Ben, a recent graduate anxious about his yet undefined future, the perfect escape from the expectations of his parents, their friends and his much older lover Mrs. Robinson: 'It's very comfortable to just drift here.' The pool feels like a movie, as does his affair (the drinks, the hotel, the pool parties), and fits perfectly in the narrative of an impasse. Both as an escape and amnesiac, Neddy in The Swimmer (Frank Perry, 1968) hops from pool to pool, remembering clichéd forbidden desires (the babysitter), a love affair gone wrong and actual financial debt, as he swims 'home', all the while realizing that there is no more home. Swimming Pool (François Ozon, 2003) associates the pool with imagination, mystery and murder, which is also the morbid conclusion of Deep End (Jerzy Skolimowski, 1970), when Mike's adolescent, obsessive desire for his co-worker Susan is finally answered as they drift lifelessly in the pool. Nanni Moretti's Red Wood Pigeon (1988) seems to be the exception that proves the rule, as the swimming pool becomes a political playground. Juxtaposing it with Besson's superficiality, Daney defends Moretti's 'refusal of depth':

Water. Filmed as never before. [...] A refusal of depth - which makes of this film the answer of cinema to the audio-visual (Le Grand Bleu). Water is a special surface that one needs to cover incessantly, ploughing it with one's body (boustrophedon). ${ }^{48}$

47 From this point of view, it is perhaps not coincidental that in French ' $n$ 'y voir que du bleu' comes to mean precisely the inability to see. Closely entangled with the expression ' $n$ 'y voir que du feu', worth the mention since we are talking about Icarus after all, this phrase etymologically goes back to La Bibliothèque bleue, which encompasses a series of French early-modern publications from the seventeenth to the nineteenth century. Typically distributed in small format, with a blue cover and on low quality paper, these booklets covered a wide range of popular subjects and came to stand for the origins of popular and mass media in France (Chartier, 2003, pp. 294-295). From this historical perspective, 'blue' gradually came to stand for 'dreamy' as in un conte bleu, a fairy tale.

48 Daney, 1993, p. 168; 'Boustrophédon', from Ancient Greek literally meaning 'ox-turning' as in farming, here refers to a bi-directional text, in which each line is written in the opposite direction as the preceding one. Rather than reading from left to right (as in English, for example), or from right to left (as in Hebrew), these manuscripts need to be read alternately from left-to-right-to-left. 
The water surface becomes workable: the swimmer, Michele, becomes its ploughman. However, here again, the protagonist suffers from memory loss, and his continued repeated shouting 'I remember, I remember!' shows a narrative that struggles with amnesia. In any case, and to use Daney's formulation, 'the new [post-modern] individual [...], in principle, should know how to swim. ${ }^{49}$

Amnesia, forgotten bodies, and forms without content: in The Big Blue as well as a series of swimming pool films, something is always lacking, and this lack goes hand in hand with highly aestheticized imagery. If I have argued before that imperfect images tend to aid authenticity, here this same logic seems reversed: gain in image equals loss of reality. And indeed, Besson's Mediterranean Sea is nothing like the ocean crossed by Thor Heyerdahl on his raft: in the former, dolphins are our friends (Jacques even calls them his family), in the latter, the sharks are a real danger that makes for an authentic but nevertheless non-existent film. The lack of 'body' in Besson, the nostalgia for content and meaning, surfaces in the water-logged, always shiny imagery of pool films as a longing for content: the image exists in all its glory, but it has lost touch with reality. Yet, Daney writes, 'the (moral) parenthesis of modern cinema being finished, cinema (or what remains of it) rediscovers the question of depth [le fond]: where do the dream bodies come from? ${ }^{\prime 50}$ In the following section, I argue that this ontological question is also a question of filiation: from the Platonic shadow plays to Aristotelian 3-D, Bazin's realist-formalist discourse can effectively be used to understand contemporary film language.

\subsection{Perspectives on 3-D}

The decisive event was undoubtedly the invention of the first scientific and, in a sense, already mechanical system: perspective (with Leonardo da Vinci's camera obscura prefiguring Niepce's darkroom).

André Bazin, 1945

As Daney writes, in Red Wood Pigeon Michele 'ploughs' the surface of the pool with his body, swimming back and forth, just like an ox works the field or a bidirectional text is read.

49 Daney, 1989, p. 161; the necessity for learning how to swim is loaded today with an immense political message, as several tens of thousands of refugees cross the Mediterranean Sea on their way to Europe. Contemporary cinema responds to this: Welcome (Philippe Lioret, 2009), for example, tells the story of Simon, a former champion turned local swimming teacher, and Bilal, an Iraqi refugee stranded in Calais. 'You want to learn to swim?', Simon asks him - 'Yes, crawl', the boy answers, and the two continue to develop an intense emotional bond through swimming classes that should help Bilal cross the English Channel.

50 Ibid., p. 146. 
The dialectic between form and content leads me, now, to briefly consider the special place Bazin reserves for the notion of perspective in 'The Ontology of the Photographic Image', in particular its role in painting as enabling the illusion of content: 'Perspective made it possible for artists to create the illusion of three-dimensional space in which objects could be placed the way they would if we perceived them directly. ${ }^{51}$ While he sees the introduction of linear perspective in fifteenth-century Western painting as a first attempt to mechanically combine 'the expression of spiritual realities in which the model was transcended by the symbolism of form - while the other was simply a psychological desire to replace the outside world with its double [my emphasis], ${ }^{52}$ he clearly denounces its usage in facilitating, for instance, 'the pseudo-realism of trompe l'œil (or trompe-l'ésprit), which is content with the illusion of form'.53 Whereas formerly the size, color and shape of objects on a canvas had been informed by their spiritual meaning, 54 linear perspective reorganizes them according to their relative distance from the spectator. From this viewpoint, Bazin denounces the painterly illusion of depth, when he writes:

[...] the art of the Middle Ages, for example, appears immune to this conflict: both violently realist and highly spiritual, it did not know the upheaval that technical possibilities have since introduced. Perspective was the original sin of Western painting.

$* * *$

Niépce and Lumière were its redeemers. ${ }^{55}$

51 Ibid.

52 Ibid.

53 Ibid., p. 11; Transl. Barnard, 2009, p. 6.

54 See, for instance, Karsten Harries' notion of 'spiritual perspective', which he juxtaposes with Alberti's perspectiva artificialis: 'The spiritual perspective of medieval art would have us look through painting in a very different sense: through the material to its spiritual significance. The mundane is transformed in a divine sign. Alberti's art is incompatible with this spiritual perspective. A God-centred art gives way to a human-centred art' (Harries, 2002, p. 85). Harries sees this conflict of perspectives reflected, for instance, in the clash between a growing interest in three-dimensionality in late Medieval painting and the use of gold. Linear perspective thus becomes entangled with the idea of a fall of man, of a profanity introduced in the history of painting with the invention of linear perspective.

In a similar manner, Dudley Andrew, in the biography of Bazin, elaborates on the notion of perspective in painting in 'Ontology' as 'the golden calf of painters' (2013, p. 65), thus invoking the theme of vanity and idolatry, which indeed runs through the essay via the double reference to Blaise Pascal's Pensées.

55 Bazin, 1945, EC p. 2556; Transl. Barnard, 2009, p. 6. 
As he does explicitly in his argument for a centrifugal screen, Bazin again places cinema in opposition to painting, here with a particular focus on perspective and three-dimensionality. Already in the summer of 1943, Bazin had started to develop his views on perspective through the analogy between cinema and Medieval painting. As Françoise Burgaud recalls that Bazin explained: 'I want to make you understand that medieval painting and cinema are the same thing! [...] These painters had tried to introduce in their works the meaning of the world, because they did not know perspective. ${ }^{5} 6$ These ideas in fact crystallize his view on linear perspective as having changed the history of Western painting, which would from then onwards be satisfied with the illusion of forms up until its redemption by the cinematograph: the conflict between form and content, impression and expression, ultimately resolved. In this manner, after the cinematograph, Bazin is able to conclude in an addition the ontology essay: 'And when, with Cézanne, form took back the canvas, it was no longer in the service of perspective's illusionist geometry.'57 With this phrase on Cézanne, Bazin readily aligns his views on perspective with those held by French philosopher Maurice Merleau-Ponty (1908-1961) in 'Cézanne's Doubt' (1945): $:^{8}$

[Cézanne] was pursuing reality without giving up the sensuous surface, with no other guide than the immediate impression of nature, without following the contours, with no line to enclose the colour, with no perspectival or pictorial arrangement. 59

Merleau-Ponty emphasizes the painter's ability to combine expression with form by leaving the illusionist geometry of perspective behind: similar to the medieval painters, Cézanne found expression outside the realm of perspective. The real problem with linear perspective, the veritable 'sin of Western painting', then, is that it inclines to emptied formalism: images cease to express meaning.

In fact, as I will establish throughout the following pages, Bazin's dismissal of the illusion of three-dimensionality created by linear perspective ties in

56 Bazin, cited by Françoise Burgaud, in Pagliano, Jean-Pierre. 'Profils perdus: André Bazin.' France culture (20/10/1988) [Radio program]; Burgaud's anecdote indeed makes one wonder whether it was perhaps the very first sketch of the Ontology essay that Bazin had started to develop that summer of 1943 .

57 Bazin, 1945, EC p. 2557; Transl. Barnard, 2009, p. 10.

$5^{8}$ As Andrew writes, Bazin was in fact in contact with the philosopher during the time Merleau-Ponty wrote the essay on Cézanne (Andrew, 2011, p. 159).

59 Merleau-Ponty, 1945, p. 12. 
with his subsequent embrace of 'relief', or three-dimensionality. Though he deals with it explicitly in his later essays, Bazin's concern with $3-\mathrm{D}$, in which he finds, again in concert with Merleau-Ponty, a more realist perspective, is already present as a constitutive element of integral realism in 'The Myth of Total Cinema':

In their imagination, they conceived of cinema as the complete and total representation of reality. From the outset, they foresaw the creation of a perfect illusion of the outside world through sound, colour and three-dimensionality.

With respect to the latter, the film historian Georges Potonniée has even gone so far as to suggest that 'it was not the discovery of photography but rather that of stereoscopy [...] which opened the thinkers' eyes'. ${ }^{60}$

Where linear perspective manipulates color, size and shape to facilitate the illusion of depth, Niepce and Lumière mechanized it. In the following pages, I suggest that Bazin completes this train of thought in his $195^{2}$ essay entitled 'Math Equations for $3 \mathrm{D}$ ', when he elaborates on stereoscopy as a decisive step towards a 'perfect illusion' of reality: synthetic relief integrates form and content rather than setting them off against each other.

\subsubsection{From a Realist Perspective: 'The Imaginary Image'}

Bazin's so-called realist-formalism effectively culminates in his embrace of stereoscopy, which he describes as an 'imaginary image' that gives body to a synthesis of both the realist and the formalist tendencies: because a three-dimensional image is formed by mentally combining two slightly diverging perspectives, stereoscopy literally imitates our direct perception and creates a 'more realist' image that paradoxically exists only in imagination. In 'Math Equations for 3D' (1952), he embarks on a rather technical explanation of three-dimensional cinema in which, beyond prophesying a future ideal cinema, ${ }^{61}$ he revives the foundations of the myth of total cinema, i.e. integral realism:

60 Bazin, 1946/1958, EC p. 2558; Transl. Barnard, 2009, p. 16.

61 Bazin was well aware of the technologies offering stereoscopic vision, as his mention of Georges Potoniée's Les Origines du cinématographe (1928) in the Myth essay indicates. Writing in 1953, then, he knew of Louis Lumière's efforts in stereoscopy and in fact subtly criticizes his disinterested, purely technical approach. The fact that the technology had existed long before it was put to use at the Festival of Britain, where Bazin encountered the poetic use of $3-\mathrm{D}$, illustrates 
If one day $3 \mathrm{D}$ cinema evolves beyond a trivial scientific curiosity, as it will likely do, directing the garden hose to spray the audience will not be enough to astonish us. The distant future of ${ }_{3} \mathrm{D}$ cinema will see a leap as great as the one from L'Arrivée d'un train en gare de La Ciotat to the train engine sequence in La Bête humaine. The labour of Mr. Spottiswoode and its still-experimental application in the films at the Festival of Britain already prove that $3 \mathrm{D}$ affords the same interpretations, with a function as orchestrated and utterly artistic as 'flat' cinema. Let us nimbly take this new and decisive step toward total cinema. ${ }^{62}$

While 'flat cinema' mechanized and thus 'redeemed' Western painting from emptied formalism, it nevertheless relies on a fixed, one-point perspective (Fig. 31): while in reality both eyes (D and G) perceive from slightly diverging points of view, they see on screen one and the same image, captured with the exact same camera lens. In today's terminology, this is referred to as a zero parallax, meaning that the discrepancy between the two projected images on screen equals zero. ${ }^{6}$ Stereoscopy, then, moves away from this abstract, cyclonic set-up towards a binocular model: the second diagram illustrates a positive parallax, where two slightly diverging images are projected simultaneously, maintaining the median distance between the right and left eye (Fig. 32). This procedure is more or less comparable to our actual perception of depth at a great distance, since the axes of each projection run parallel (the discrepancy on screen equals the distance between the eyes). This type of stereoscopy, however, has the disadvantage that objects at close distance will appear blurred or cause discomfort: 'When I look at the end of my nose, I go cross-eyed and work hard to see clearly. But at the cinema, I dissociate these two physiological actions. ${ }^{64}$ Even though the camera is equipped with two lenses, it is nevertheless forced to remain static, since a rapid succession of planes involving different depth cues would

his argument against the mere industrial demand or scientific invention of film and in favor of myth, which includes the imagination and artistic use of those technologies.

For a comprehensive historiography of stereoscopic cinema, see for example Zone, 2007 and 2012. See also the recently published Ross, Miriam. ${ }_{3}$ D Cinema: Optical Illusion and Tactile Experiences (2015), especially her chapter on 'New Realisms' (pp. 72-94).

62 Bazin, 1952c, EC p. 966; Transl. Andrew, 2014, p. 241.

63 The parallax is the degree of perspectival difference between two diverging points of view, which lies at the basis of our perception of depth. Because of the distance between our left and our right eye; on different parallax classifications used to create stereoscopic vision, see: Stereographics Developers' Handbook. Stereographics Corporation (1997): pp. 9-10 <http://www. cs.unc.edu/Research/stc/FAQs/Stereo/stereo-handbook.pdf>.

64 Bazin, 1952c, EC p. 965; Transl. Andrew, 2014, p. 240. 
tire our brain (which is where the images are put into focus) and enhance such cross-eyed outcome. The true 'revolution in three-dimensionality' that reminds Bazin of the integral realism he had envisioned in 'The Myth of Total Cinema' is the creation of depth in front of the screen: by inverting the axes of projection on screen, a negative parallax creates the point of convergence in between the screen and the spectator (Fig. 33). Owing to specific calculations of British film theorist Raymond Spottiswoode (19131970), this convergence in the projection could be calculated depending on the actual distance between the camera and the filmed objects. Bazin encountered the results of this invention at the Festival of Britain in 1952, where Spottiswoode had commissioned Canadian filmmaker Norman McLaren (1914-1987) to produce 3-D animations based on these principles. ${ }^{65}$ The resulting films, Around Is Around (1952) and Now Is the Time (1952), were, according to Bazin, 'revolutionizing the field of animation with his brilliance and poetic sensibility. [...] abstract painting in motion and in 3-D' [emphasis in original]. ${ }^{6}$

When Bazin envisions a future cinema in three dimensions by comparing Lumière's train to the sequence in The Human Beast (Jean Renoir, 1938), he is not merely imagining this train in 3-D for the sake of making a clever film-historical reference. The train arriving at La Ciotat could have easily been recorded using a positive parallax, because the camera remains static throughout the entire period of shooting. In fact, by 1903 Lumière had already successfully recreated the sequence in stereoscopy; he had patented his ideas on this technology at the turn of the century, and published an essay under the title 'Stereoscopy On the Screen' in 1936, which I will discuss later on in this chapter. ${ }^{67}$ Renoir's famed train sequence, quite the opposite with its rapid succession of shots captured by a camera moving at train speed, would only be possible in three dimensions by means of 'synthetic $3 \mathrm{D}$ ' because of its relative axis of convergence, 'corresponding to the normal angle of vision in the real world'. ${ }^{68}$ Bazin's train examples are telling: of course, he attributes the curiosity element to Lumière and the 'great artistic use' to Renoir's famed train sequence, which in Bazin's days had not yet been filmed in 3-D. One could indeed think that Bazin juxtaposes the static camera of Lumière to Renoir's train, which penetrates space, because the

65 Zone, 2012, p. 401.

66 Bazin, 1952c, EC p. 966; Transl. Andrew, 2014, p. 241.

67 See: Zone, 2007, pp. 141-143; Lumière's essay can be found in Journal of the Society of Motion Picture Engineers, Vol. 27, No. 3 (September 1936): pp. 315-320.

68 Bazin, 1952c, EC p. 964; Transl. Andrew, 2014, p. 236. 

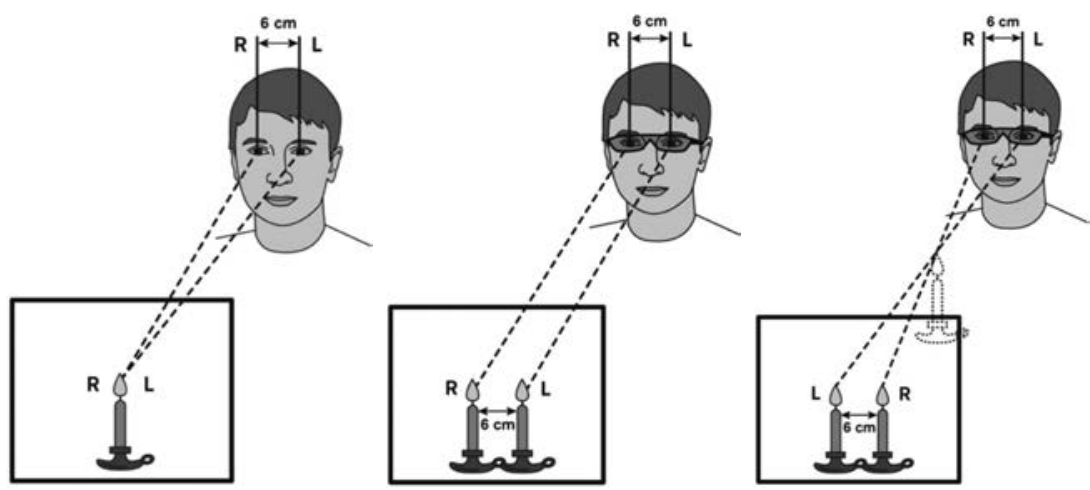

Fig. 30-32 Diagrams on parallax view

moving train could not be shot with a positive parallax. Yet Bazin's claim is bigger here, as these train sequences are the exact examples he uses in his text 'Language of Our Time':

The spectators of the Grand Café understood that a train was rushing towards them, but nothing is more hypothetical than the extrapolation that would consist of thinking that they would have understood the accelerated montage of the locomotive on the loose used 25 years later by Abel Gance in The Wheel [...]. It's precisely that between L'Entrée du train en gare de La Ciotat and the silent cinema of the 1920s, there is already a great depth of language, which is montage. The first was content with showing an advancing train [...] The point of Gance is exactly not anymore to show a locomotive going faster and faster but, by means of the temporal and spatial relations implied by montage, to signify speed. ${ }^{69}$

Of course, he does not evoke Abel Gance's train from 1923 in an argument on 3 -D, but more generally to make the point of a fundamental evolution in film language: Lumière showed an accelerating train, Gance signified it. 'This difference is important', he continues, '[i]t is quite simply at the basis of thought as language: the decisive passage from concrete to abstract. The birth of a semantic and of a syntax'.$^{\circ}$ Will 3 -D ever reach this stage of signification, or is it doomed to remain a special effect? I will come back to this in the concluding section of this chapter, but for now it is important to highlight Bazin's particular semantics, also discussed in the previous 
chapter: beyond semiotics, which typically dissociates signifier (form) and signified (content), cinema can signify in a concrete way.

The juxtaposition of these iconic trains in film history anticipates a series of references that articulate three-dimensionality as the integration of image with reality or form with content. In the introduction to "The "Return" of 3-D' (2013), appropriately subtitled 'Trains of Thought', Thomas Elsaesser engages in the current discourse on three-dimensionality, which he considers not merely as a special effect but rather as 'a different kind of mental image ${ }^{71}$ involving a veritable paradigm change. Like Bazin, he references Lumière and Renoir's trains, both condensed in a sequence from Martin Scorsese's 3-D Hugo (2011), in which the little boy has a nightmare involving the derailment of a train at the Montparnasse station:

[...] for the cinephile, there is an in-joke within the in-joke within the in-joke. The train seen roaring twice into the station is not just any old train from the 1920 . It is the digitally enhanced proleptic train from Jean Renoir's 1938 La Bête humaine, complete with Jean Gabin's begoggled sooty face leaning out of the locomotive; Scorsese's mise en abyme of film history in reverse is giving us this train wreck as an in-joke in 3-D, considered as a temporal anamorph rather than an optical effect. ${ }^{72}$

To add to these ongoing cross-references (again: recreations, or cinephile filiation), the visual effects of the train landing in a heap were in fact entirely inspired by the historical photograph of an actual derailment at the Montparnasse railway station that had occurred about a week before the Lumière brothers' first screening. ${ }^{73}$ From this point of view, Scorsese revisits in this dream sequence the so-oft cited and debunked 'origin myth' of cinema: Lumière's terrified spectator would have been unable to dissociate the moving image of an approaching train from reality. On this topic, Tom Gunning, for example, writes: 'Far from fulfilling a dream of total replication of reality - the apophantis of the myth of total cinema - the experience of the first projections exposes the hollow centre of the cinematic illusion. ${ }^{74}$ However, in an attempt to nuance the story's by now fabled status, Ray Zone

71 Elsaesser, 2013, p. 218.

72 Ibid., p. 217.

73 Legato, Rob. 'Hugo and the Joy of Filmmaking.' CreativeCOW.net [Accessed 21/02/2015] <https://library.creativecow.net/legato_rob/magazine_30_HUGO/1>.

74 Gunning, 2004, p. 91; also see Loiperdinger, 2004, pp. 89-118. 
adds to its mythical origins that it seems highly likely that this train disaster may have been on the minds of Parisian patrons viewing L'Arrivée d'un train at the Grand Café and affected their response to the motion picture image of an approaching locomotive'.$^{75}$ Imagine a box-office release involving collapsing towers in the aftermath of September 11, or a train crashing into Spanish theaters following the Santiago de Compostella derailment in July 2013: such disastrous events show reality to be stranger than fiction, and shocked reactions to their depictions are perhaps less related to a naive mistaking of fiction for reality but may instead arise as a result of collective trauma. The implied convergence between history and fiction in Scorcese's sequence of trains, then, projects new light on the mythical status of Lumière's train. Hence, another 'in-joke' completes this chain of trains in 3-D: Louis Lumière, Jean Renoir, Martin Scorsese and somewhere in between André Bazin, whose notion of stereoscopy as an 'imaginary image' now appears more than ever as 'a really existing hallucination' ${ }^{7}$

Beyond affirming, once again, the importance of recreation in criticism, this short excursion on cinematic trains brings me back to the core of Bazin's views on perspective, condensed in the reference to Cézanne and synthesized in his embrace of synthetic relief. While Lumière's original (2-D) train sequence is arguably already an exercise in 'stereoscopic aesthetics',77 the static camera position reveals its reliance on analytic geometry to create depth. Bazin's elaborate technical explanations suggest, on the contrary, that the more realist perspective of stereoscopy, i.e. the mental convergence of two distinct images into one three-dimensional image, is neither linear nor is it indeed photographic. In a similar vein, Merleau-Ponty, who may have had Lumière's train in mind, puts it this way in his essay on Cézanne:

[...] the lived experience, that which we actually perceive, is not a geometric or photographic one. The objects we see close at hand appear smaller, those far away seem larger than they do in a photograph. (This can be seen in a movie, where a train approaches and gets bigger much faster than a real train would under the same circumstances. $)^{78}$

75 Zone, 2005, p. 147; Zone's anecdote in fact calls to mind Bazin's notion of film as a social documentary, which highlights the hallucinatory nature of reality and vice versa (see 3.1.3 'How Everything Turns Away': Icarus as Anti-War Statement).

76 Bazin, 1945, EC p. 2557; Barnard, 2009, p. 10.

77 For a detailed analysis of depth in L'Arrivée du train, see Loiperdinger, 2004, pp. 102-107.

78 Merleau-Ponty, 1945, p. 14. 
From this viewpoint, objects on the flat cinema screen appear closer than they really are. ${ }^{79}$ Here, again, Bazin seems to follow Merleau-Ponty's description of 'lived perspective' when he praises stereoscopy's perspectival apparatus as 'an eye for an eye'. Moreover, the shift from analytic to synthetic relief proposed by Spottiswoode literally does away with the flat surface of the image, which is now mentally 'imagined' in between the screen and the spectator: '[...] a perfect illusion of the outside world through sound, colour and three-dimensionality. ${ }^{80}$ Surprisingly, the more realist the perspective, the more the image becomes imaginary; the synthetic image is, as Bazin writes, 'an imaginary image' that is mentally put into focus in between the screen and the spectator. In short, the image ceases to exist as such and instead gives way to an enhanced realism. The imagination of cinema had never felt so real!

The reference to the trains in Bazin's citation, then, is a subtle repetition of the objections he had made against the inventors and in favor of an imagination of cinema. Lumière's train, even re-shot in 3-D, does not exceed the level of 'scientific curiosity', whereas Bazin envisions the signification of a train in full speed and in three dimensions: 'a function as orchestrated and utterly artistic, as "flat" cinema, ${ }^{81}$ Bazin's careful dismissal of Lumière's writings on stereoscopy, or indeed his 3-D version of the arrival of the train, runs along the lines of his myth as the imagination rather than the inventions of cinema. In fact, the contextual reference with which Bazin opens 'Math

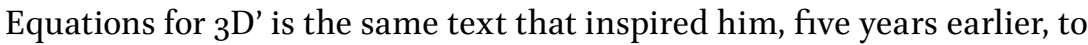
write 'The Myth of Total Cinema': Georges Sadoul's first volume of the General History of Cinema on the invention of cinema. As I will establish, this is not a coincidence: where the first essay is a strong justification of the talking film, the latter aspires to recall this agenda in support of cinema in 3-D - a vital component, alongside sound and color, of integral realism.

\subsection{2. 'Will This Be the Triumph of the Fat?'}

In many ways, the dry and scientific tone of Louis Lumière's essay on stereoscopy illustrates his more general disinterest in the future

79 On the effects of such distortions during the Lumière projection, see Loiperdinger, 2004, pp. 103-104: 'Every object is reduced in size by the square of its actual distance from the camera's lens. Objects filmed close up appear larger; those filmed from afar seem smaller than we are used to from human spatial perception. [...] This cinematic effect makes the approaching and seemingly rapidly growing locomotive on the screen appear to be accelerating while, in reality, the locomotive arriving at the station is slowing down.'

8 o Bazin, 1946/1958, EC p. 2558; Transl. Barnard, 2009, p. 15.

81 Bazin, 1952c, EC p. 966; Transl. Andrew, 2014, p. 241. 
artistic possibilities of the technologies he invented. ${ }^{82}$ His apathy in fact becomes all the more striking when juxtaposed with the ideas on the same topic of a visionary such as Sergei Eisenstein (1898-1948), who in 'On Stereocinema' (1947) goes as far as to applaud three-dimensionality as a new artistic form that enables the elevation of post-war consciousness. He writes:

What of consciousness, struggling tirelessly in these post-war years to forge a concrete model of a genuinely democratic international ideal? Are they not clamouring for artistic expression of wholly new, never-before-seen forms and dimensions, far beyond the limits of the palliatives proffered by traditional theater, traditional sculpture, and traditional ... cinema? To be sure, the new, dynamic stereosculpture will toss traditional, static sculpture - with its yardstick, still wielded by the likes of Chavance - beyond the limits of dimensions and unique qualities.

We must not fear the advent of a new era in art. ${ }^{83}$

A brief digression into this former discourse via Eisenstein's essay shows that he takes on a similar critical agenda as Bazin did back in 1946. Both critics are offended by an elitist dismissal of a novel technology brought to the screen; and Eisenstein, traditionally more of a formalist than a realist, holds views on 3-D that are remarkably similar to Bazin's. He begins his elaborate study of stereoscopic cinema with an apology that derides the opposition:

These days you run into a whole lot of people asking: 'Do you believe in stereocinema?' To my mind this question sounds about as absurd as if they were to say: do you believe that it will be night-time at midnight, that one day the snow in the streets of Moscow will melt away, that there will be green trees in the summer and apples in the fall? That today will give way - to tomorrow! To doubt that tomorrow belongs to stereocinema is just as naïve as it is to doubt the very coming of tomorrow! [...] How is it, indeed, that we are able to make such bold predictions? The answer is that no species of art is truly capable of survival unless it bears in its essential character some aspect of our deepest yearnings and aspirations. ${ }^{84}$

82 In an interview with Georges Sadoul in 1948, Lumière would have stated clearly that his interest in stereoscopy was purely scientific (Zone, 2007, p. 143).

83 Eisenstein, 1947, p. 56.

84 Ibid., p. 20. 
One of those people in disbelief about 3-D was Louis Chavance (1907-1979), French screenwriter and critic at Revue du cinéma, who Eisenstein accuses of 'wilful obscurantism' ${ }^{85}$ when he dismissively wrote: 'is this technological discovery able in some way to heighten the dramatic tension of a scene? Does an actor, represented in three dimensions, find there some additional expressive means? A physical plumpness? ... Will this be the triumph of the fat? ${ }^{86}$ In reaction to such opinions, Eisenstein interestingly resorts to 'deep-seated human needs, ${ }^{87}$ with three-dimensionality being 'the most thorough and immediate expressions of such aspirations. ${ }^{88}$ Again much like Bazin, Eisenstein argues that this third dimension meets such inherent human needs by integrating image and reality (Eisenstein calls this binary set 'Fiction and Reality'), when he writes:

Here these two 'partners' are understood as the embodiment of two fundamentally distinct realms, divided by the rampe; the realms of Fiction and Reality. ${ }^{89}$

And:

Not only had cinema - that ultimate stage in the developmental history of the theatrical art - realized successfully the tendency to reunite spectator and performer, it was also able to merge the realm of Fiction with that of Reality, transformed by an artistic will..$^{9}$

The parallels between Eisenstein's praise of 3-D and Bazin's notion of integral realism appear to bring out the formalist side of Bazin's realism; conversely, Eisenstein's 'social interpretation of reality' ${ }^{\text {'91 }}$ shows the realist element in his ardent formalism, i.e. fiction as it relates to reality. Three-dimensionality adds volume, quite literally more image on screen, and at the same time brings about an increase in realism: it lessens the gap between film and reality. Whereas

85 Ibid., p. 55 .

86 Louis Chavance (1946), cited in ibid., p. 55 .

87 Ibid., p. 26.

88 Ibid., p. 21.

89 Ibid., p. 47; Eisenstein's mention of the rampe, which are the footlights that illuminate the actors on stage and thus separate them from the audience, draws parallels between stereoscopy and the theater. Having been actively involved with the theater before his career as a film director, it should come as no surprise that a major part of the essay on 3-D seeks the precursors of this novel technology in the theater.

90 Ibid., p. 49.

91 Ibid., p. 26. 
three-dimensionality was dismissed by some critics as mere 'physical plumpness' with no expressive means, both Eisenstein and Bazin thus considered it a potentially revolutionizing technique. In short, from a realist-formalist perspective, 3-D in and of itself, either as an imaginary image or as Fiction and Reality combined, embodies the synthesis of form and content.

\subsection{Bazin Put to the Test: Godard and Wenders}

To refuse or not to refuse depth: in today's film criticism, this still appears to be a concern. For example, a contemporary critic of 3-D writes, confidently: 'I cannot imagine a serious drama, such as Up In the Air or The Hurt Locker, in 3-D.92 But is rashly rejecting this technique based on its previous abundant use in spectacular cinema not precisely like discarding continuous soundtracks, color or indeed movement on screen? From a more realist perspective, the imaginary image of 3 -D does precisely that: integrating image and reality, turning every image into an object and every object into an image. Yet, there exists a convinced and ardent opposition to 3-D in today's critical discourse, which Thomas Elsaesser groups under the unheard voices of the 'Cassandras of 3-D':

[...] despite such high-calibre interest and endorsement, another prestigious and reputable consensus holds that the wave has already peaked, that the revival is sputtering, and that the operation has never been a success, either economically or aesthetically. 93

Admittedly, from an economic point of view, the film industry is today again facing a real threat, not from television, as it did in the 1950 s when 3 -D first peaked, but from the internet: 3 -D is 'reaching out of the screen [...] and robbing your wallet'. ${ }^{4}$ From the perspective of myth, however, such reasoning shows itself to be a speculative fallacy that is fundamentally distinct from aesthetics and risks gagging cinema for a third time in history: first the talking film, then Besson's aphasic images as the highpoint of a crisis of scenarios, today the financial suicide attempt of an art form. Contemporary

92 Ebert, Roger. 'Why I Hate 3D.' Newsweek (05/10/2010) < http://www.newsweek.com/ roger-ebert-why-i-hate-3d-movies-70247>.

93 Elsaesser, 2013, p. 218.

94 Kirsten Thompson, cited in Elsaesser, 2013, p. 219; see pp. 219-220 for a concise overview of recurring arguments against $3-D$. 
critiques of 3-D cinema - whether they emphasize its lack of content, portray it as unfit for regular storytelling or consider it as an industrial gimmick - can in fact be understood as a repetition of this former discourse. Yet, with recent films like Jean-Luc Godard's Adieu au langage (2014) and Wim Wenders' Every Thing Will Be Fine (2015), Bazin's twofold wish for an artistic and consorted use of three-dimensionality becomes more tangible. Concluding this chapter on 3-D, I argue that each of these filmmakers, adding to an already extensive and established oeuvre, affirms either through drama or as a film essay that 3 -D now belongs to the language of film.

\subsubsection{Goodbye to Language}

Si la perspective fût le péché originel de la peinture occidentale, la technique était son fossoyeur. La conquête de l'espace fit perdre la mémoire à tous. [Ifperspective was the original sin of Western painting, technology was its gravedigger. The conquest of space made us all lose memory.]

[emphasis in original] Jean-Luc Godard, Les Trois Désastres, 2013

In his first 3-D film-essay Les Trois Désastres (2013), Godard recites the phrase on perspective from Bazin's 'Ontology' essay - 'La perspective fût le péché originel de la peinture' 95 - with yellow streetlights superimposed over an image of the Madonna against a dark-blue background. Godard is known for quoting Bazin,${ }^{96}$ and this specific sequence offers itself as a condensed moment in a succinct scheme for a new cosmology of cinema, in three dimensions. From a contemporary point of view, Godard revisits Bazin's critique of illusionist perspective, applied to 3-D cinema: 'You see, Sergei, you have felt that there is no space in the Kremlin and not in San Francisco either, isn't that true Orson Welles?' The fear of emptied formalism, of meaninglessness and memory loss, clearly runs through Godard's inaugural manifesto for $3-\mathrm{D}$; or is it its requiem? His rather cynical allusion to Titanic 3- $D$ (James Cameron, 1997) - 'and then, depth; depth! Declares the professor of the Titanic' - appears to suggest an overall sarcastic tone

95 Bazin, 1945, EC p. 2556.

96 'I think that one should cite Bazin in every article on cinema' (Jean-Luc Godard, cited in Joubert-Laurencin, 2014, p. 14); See also the citation in the opening scene of Le Mépris (1963), in which Godard claims Bazin would have said that 'cinema substitutes for our gaze a world according to our desires'. While it definitely has some bazinian undertones, this statement was in fact uttered in 1959 by Michel Mourlet, film critic at Cahiers du cinéma (see: Joubert-Laurencin, 2014, pp. 37-39). 
vis-à-vis 3-D technology, which is confirmed by a superficial reading of the film's title: the three disasters, the 3 D's. Taken literally, les trois désastres indeed appears to be a foreboding for his subsequent 3-D film, Adieu au langage (2014): from three disasters follows an excess of imagery that disables communication and meaning. In Adieu au langage, Godard criticizes the empty, meaningless images that flood our contemporary screens under the 'dictatorship of the digital'. The nostalgia to which he still holds on in Les Trois Désastres is replaced by rather grim Instagram aesthetics: iPhones and Google, so he suggests, have replaced our books and our knowledge. Again, superficially, the title gives a negative impression when it comes to the expressive means of $3-\mathrm{D}$, a goodbye to language for lovers stuck in miscommunication: 'Make sure that you can hear me', she repeatedly says, to which he answers: 'make sure that I can speak'.

Read differently, Adieu au langage [Goodbye to Language] transforms via intertitles into 'Ah Dieu, oh langage [Ah God, oh language]'. And indeed, more than a farewell, the film is an affirmation of the possibilities to reinvent the language of cinema: as the cinematographer Fabrice Aragno puts it, 'we weren't interested in using 3 -D as an effect. The film had to be about using 3-D to express new things. ${ }^{97}$ Godard includes, among many innovations, nudes descending a staircase in $3-\mathrm{D}$, and he constantly plays with layering, double exposures and superimposition. Changing the parallax degrees, for example, causes the two layers that combined produce the 3-D effect to suddenly split, forcing each eye to follow a different image cross-eyed. Godard's most recent investment in 3-D, then, not only 'breaks the rules of $3-\mathrm{D}^{\prime 98}$ but creates new ones altogether. Aragno explains that in order to achieve this, he:

built a rig to separate the images, which happens at several points in Goodbye to Language, and I first did a test with two friends. I had them stand together in a shot, and then I asked the boy to walk away, over to the kitchen. I followed him with the right camera, while the left camera stayed on the girl. You suddenly have two images, with the girl on the left, and the boy on the right, and your brain begins to mix the two. Then I had the boy walk back to the girl, and the 3-D image returns. It hurts a bit when you watch it. ${ }^{99}$

97 Fabrice Aragno in Dallas, Paul. '1+1=3.' Film Comment (November/December 2014) <http:// www.filmcomment.com/article/fabrice-aragno-interview $>$.

98 See: Frazer, Bryant. 'Five Ways Jean-Luc Godard Breaks the ${ }_{3} \mathrm{D}$ Rules in Farewell to Language.' StudioDaily (03/10/2014) < http://www.studiodaily.com/2014/10/ five-ways-jean-luc-godard-breaks-the-3d-rules-in-farewell-to-language/>.

99 Aragno, cited in Dallas, 2014, n. pag. 
The result of this experiment was called shot of the year by the critics when the film was released, as it pushes the limits of cinematographic language: 'It's montage taken to its logical extreme: in-eye editing. This isn't simply a great shot - it's a new kind of shot altogether.' ${ }^{100}$ David Bordwell, admitting he was wrong when he had previously dismissed the potential of $3-\mathrm{D}$, sees in it the 'temptation to close one eye, then the other, in creating your own shot/reverse-shot editing'. ${ }^{101}$

Already in his first 3-D essay, Godard returns to language, more precisely to poetry, when he has an excerpt from Charles Baudelaire's The Voyage (1861) whispered over a superimposition of a ferry on the shimmering surface of the ocean and a piano play, altogether creating some sort of double 3-D:

\section{Nous avons vu des astres}

Et des flots, nous avons vu des sables aussi;

Et, malgré bien des chocs et d'imprévus désastres,

Nous nous sommes souvent ennuyés, comme ici.

La gloire du soleil sur la mer violette,

La gloire des cités dans le soleil couchant,

Allumaient dans nos cours une ardeur inquiète

De plonger dans un ciel au reflet alléchant.

[We've seen the stars

And waves, and we have seen the sandy shores;

Despite disasters, all our jolts and jars,

On sea, on land we find that we are bored.

The glorious sun across the violet sea,

Great sunlit cities dreaming as they lie,

Made our heart yearn with fierce intensity

To plunge towards those reflections in the sky. $]^{102}$

The title now becomes 'the three stars', like those in Van Gogh's Starry Night, which Bazin in a liberal poetic turn described as 'three suns', alluding to the sunflowers as motifs of a new cosmology of film discussed extensively in the previous chapter. Not much later, a woman will fall from the sky, impaled

100 Marsh, Calum. 'The Shot of the Year.' The Dissolve (19/12/2014)<https://thedissolve.com/ features/2014-in-review/866-the-shot-of-the-year/s.

101 Bordwell, David. 'Adieu au langage: 2+2x3 D.' Observations on Film Art (07/09/2014)<http:// www.davidbordwell.net/blog/2014/og/o7/adieu-au-langage-2-2-x-3d/>.

102 Baudelaire, 1861, pp. 308-309; Transl. McGowan, 1993, p. 513. 
by the mast of a sailboat; or is it, as the subsequent shot suggests, the crane of a camera? The fall of Icarus has gone terribly wrong: boredom, despite unforeseen disasters. 'Those who lack imagination', the voice-over in Adieu au language narrates, 'seek refuge in reality'. Nevertheless, to dive into the sky, to fly with your arms, affirms imagination as the transformative force of poetry. Baudelaire writes, 'Nous voulons voyager sans vapeur et sans voile! [We want to travel without wind or sails!],' to which Valéry adds: 'Le vent se lève! [The wind rises!]'

\subsection{2. $\quad 3-D$ as Realist Grammar}

Still, my deepest desire, or biggest hope, is that this future 3 -D cinema will in fact ignite a new interest in the act of seeing. In the physiology and psychology Of what our eyes and our brains do together, in unison, In the most amazing perfection, To create space, depth, volume and presence. [emphasis in original] Wim Wenders, 2013a

With his recent return to fiction in Every Thing Will Be Fine (2015), followed by The Beautiful Days of Aranjuez (2016) and Submergence (2017), Wim Wenders confirms that his initial interest in 3-D for Pina (2011), a dance documentary about the German choreographer Pina Bausch, and for his subsequent documentary on architecture, Cathedrals of Culture (2014), was not short-lived. In fact, after years of experimenting with this new technology, Wenders is now one of the most outspoken defenders of 3-D, which he sees, against the big Hollywood studios, as capable of a 'realist grammar':

Human reality. Our planet. Our existence. Our concerns. But: I am convinced that this is what 3-D was invented for and what it can do. [...] It should/it will/it must become the very language of future-reality based movies, documentaries as well as fictional films. It is absurd that the contemporary notion of a 'fictional film' means, for more and more people today, that it is not related to any reality. That is a cultural disaster; a tsunami wiping out our imagination. Stories are rooted in myth, and myth is distilled from human experience, from life. [...] 3-D belongs in the hands of documentary filmmakers, of independent writers, directors, authors, of people willing and able to forget limits, rules, formulas, recipes, 
and enter a whole new age of cinema, where there is more... connexion.

Existential connection. $3^{-D}$ has that connecting power... ${ }^{103}$

Wenders makes a clear statement about putting 3-D technology back into the hands of filmmakers who can reclaim this technology as part of the language of film: to make films speak again. His choice to use 3-D for Pina relied, in the fashion of Eisenstein, on concepts that are typically associated with the theater: an emphasis on a newfound presence and interpersonal closeness. It enables what Wenders calls a connexion, all the while without resorting to what Bazin calls the 'hyperbole' of overacting, a direct consequence of the gap between audience and stage: 'The stage thus incites [the actors], even obliges them, to indulge in hyperbole. Only in film could Charlie achieve his perfect mathematics of situation and gesture, to convey the greatest degree of clarity in the least amount of time. ${ }^{104}$ It is therefore no coincidence that, for Wenders, 'the most exciting experience was the simplest one: close-ups'. ${ }^{105}$ The intimate close-ups of Bausch's dancers are not only the most simple, least spectacular cinema experience but also the least theatrical and therefore perhaps the most specific to 3 -D. In this manner, they somehow already stand in opposition to the common assumption that 3-D only cares for spectacle, which dance to a certain extent still is. In 2013, then, Wenders writes that 'the 3 -D I am dreaming of will be pleasant to the eyes, it will not hit you over the head, it will never feel like a roller-coaster ride. It must feel natural and unpretentious. Sincere! The opposite to gimmicky'. ${ }^{106}$

With Every Thing Will Be Fine, Wenders takes on these principles of 3-D as a realist grammar as he returns to fiction after a series of documentary films. The opening scene shows Tomas in his writer's shed, sharing artistic struggles with the local fishermen on a frozen lake in Québec: he writes two pages a day, which is actually not bad at all. When he has his girlfriend on the phone, it becomes clear they have conflicting expectations and that their relationship is tilting: she wants a child, he simply wants to be able to write. 'You're a good writer, Tomas', she assures him, but her kind words are quickly dismissed as empty and meaningless. In the car on his way home, he returns her call with an apology: 'everything will be different from now on'. And it will be: the road is icy and when two children on a sled cross his path, fate hits inevitably as Tomas accidentally kills Christopher's little

103 Ibid., pp. 172-173.

104 Bazin, 1951c, EC p. 710; Transl. Barnard, 2009, p. 164.

105 Wenders, 2013a, p. 169.

106 Wenders, 2013b, p. 223. 
brother Nicolas. From this very moment, nothing will ever be the same, for Tomas, Christopher or his mother Kate. Tomas' guilt is at first unbearable, but it soon becomes clear that the traumatic event is making him a better writer - perhaps even a better person? When Christopher, who appears to have developed an obsession with the writer, recognizes a scene in his latest best-selling novel as based on their first encounter the evening of the accident, one cannot but wonder: how far can a writer, or a filmmaker, go in fictionalizing someone's lived suffering? 'An author writes partly based on reality and imagination', Tomas reassures him; and indeed, his somewhat naive smile directed to the audience in the final shot of the film, unconventional in its simplicity, conveys consolation and confidence that the two can go together.

Throughout the film, Wenders shuns spectacle. ${ }^{107}$ The sequence when Tomas realizes there were in fact two children on the sled (and that therefore, he must have hit the second) expresses the terror of the moment in a way that no crash or obvious blood could have done. Kate's grief when she sits at the kitchen table feels very real, and the frequent overlays, either superimposing two images or working with mirroring surfaces, convey a most concrete closeness between characters on screen and with the audience. Shooting and editing 3 -D, Wenders explains, entirely changes the filmmaking experience as well as the effect of the images on the audience:

3-D has a built-in capacity to involve you in a different way than 'flat cinema' does. It even involves different areas of your brain! So, one can certainly tell a story differently. In 3-D, I come up with different shots, I edit differently, I look at my actors differently. We are involved differently, myself as well as my audience, so don't you think an intimate drama could also come out differently?108

In fact, the most remarkable effect of 3-D in Every Thing Will Be Fine is, precisely, that it immediately feels normal and goes almost unnoticed:

107 Ironically, though, it is precisely for this reason that several critics have labelled Wenders' latest film as 'tone-deaf and structurally haphazard' (Lodge, Guy. 'Every Thing Will Be Fine.' Variety $(10 / 02 / 2015)<$ http://variety.com/2015/film/reviews/berlin-film-review-every-thing-will-befine-1201429546/>), or ironically labelled 'a fine film!' (Pattinson, Michael. 'Wim Wenders' Every Thing Will Be Fine is a Major Disappointment.' Indiewire (10/02/2015) <http://www.indiewire.com/article/ berlin-review-wim-wenders-every-thing-will-be-fine-is-a-major-disappointment-20150210 $>$ ). 108 Wim Wenders, cited in Roxborough, Scott. 'Wim Wenders on How 3 D Is Drowning "In a Lack of Imagination" (Q\&A).' The Hollywood Reporter (02/05/2014) <http://www.hollywoodreporter. com/news/berlin-wim-wenders-how-3d-677303>. 
natural, yet profoundly moving and intimate. Wenders' choice for 3 -D was a straightforward and deliberate one: to find pictures in reality, and to find reality in pictures. For example, one scene in particular is based on the American painter Andrew Wyeth's Wind from the Sea (1947), in which a laced curtain with embroidered little birds flows lightly into an attic window:

I found some of Wyeth's pictures, so to speak, in Kate's house, and it was wonderful that the curtains in the film were moved by real wind, and not by a ventilator, with the yellow soy field in the background and this beautiful tree right in the middle. With that small intimate scene in the kitchen, you could feel that 3 -D was dead right for the film and see how it literally 'places' you in the emotional space of these people. ${ }^{109}$

Wenders often frames his shots through windows, and their resistance to complete transparency best conveys the real splendour of 3 -D. The waving curtains in Kate's kitchen window are truly awe-some, and together with many shots that include a surface - reflecting windows mostly (or water surfaces in Godard) - these are precisely the moments when 3-D feels necessary.

Like Godard's active engagement with the linguistic potential of 3-D, Every Thing Will Be Fine reclaims so-called platitudes: the title, Wenders explains, conveys 'something of a fairy tale which we took for something very real." ${ }^{110}$ Etymologically derived from the French plat, meaning flat, these sentences regain their depth and meaning, literally in three-dimensionality. From this perspective, the mourning and healing process all the characters go through parallels the enigmatic space in the film's title between 'every' and 'thing':

It's my hope that our 3-D CinemaScope images won't become part of this never-ending and arbitrary avalanche, that they are self-contained, and will achieve what my favourite film philosopher of the 20s, Béla Balázs, said: 'Cinema is capable of securing the existence of things.' (This is the main reason why our title also has 'everything' written in two words: Every Thing, every single thing must be set right for Tomas, Christopher and Kate.) Despite this flood of digital photos and film, I still think we

109 Wenders, Wim. 'Every Thing Will Be Fine: An Interview with Director Wim Wenders.' The Upcoming (10/02/2015)<http://www.theupcoming.co.uk/2015/02/10/ every-thing-will-be-fine-an-interview-with-director-wim-wenders/>.

110 Wenders, Wim. 'Every Thing Will Be Fine | Press Conference Highlights | Berlinale 2015.' YouTube $(10 / 02 / 2015)<$ https://www.youtube.com/watch?v=6yI7Coegzy8\#t=45>. 
can make use of composed images and precise storytelling to achieve exactly this: illustrate and preserve the existence of things and people. Images don't have to be constantly surging waves, they can also be the firm rocks in that sea. ${ }^{11}$

If 3 -D were to be used only as a tool for spectacle disconnected from reality, Wenders argues, 'this fantastic language is about to drown in a lack of imagination'. ${ }^{112}$ Rather than taking part in a wave of meaningless images, 3 -D holds the real capacity to put meaning back into platitudes - in Bazinian terms, to 'save being by appearance'. ${ }^{113}$ While everything turns away, every thing will be fine. Having reclaimed this technique as realist grammar, cinema exists as the integration of imagination and reality.

As it is the case in Wenders and Godard, eloquence (or the lack thereof) accompanies Bazin's approach to the evolution of film. Indeed, he often oscillates between the affirmation of speech on the one hand and an acceptance of failures in direct communication on the other hand. From the perspective of speech impediments, I have elaborated on both harmony and disruption in the form-expression equation, throughout and beyond Bazin: e.g. Charles Baudelaire's aphasia as well as Bazin's own stutter, Charlie's gibberish and the Great Dictator speech, Serge Daney's critique to an amnesiac cinema of forms without body, and the 3-D poetry of Jean-Luc Godard as well as Wim Wenders' realist grammar. Bazin's understanding of form and content thus presents a radically new approach to the evolution of film language, which runs alongside his equally original conception of integral realism.

\subsection{VR: Complete Film, or Total Cinema?}

From color, to sound and 3-D: writing in the forties and fifties, Bazin knew all these techniques, and to defend their artistic potential, he resorts to the critical and theoretical pitfalls of generations before him. Let us recall Bazin's defence of sound cinema, facing critical rejection because of its low realism: 'Intellectuals don't like to be interrupted. When the screen started to talk, they kept quiet.'114 From this perspective, Bazin is anything but nostalgic when he writes:

111 Wenders, cited in The Upcoming, 2013.

112 Wenders in Roxborough, 2014, n. pag.

113 Bazin, 1945, EC p. 2555.

114 Bazin, 1943b, EC p. 76. 
Along with the influence from established art forms comes the impact of [cinema's] technical evolution [...] Within a few months the birth of sound came to annul its aesthetic victories. Today colour, tomorrow relief and television will come to jeopardise the fruits of 20 years of sound cinema. ${ }^{115}$

Virtual Reality, which was then not yet invented, in fact follows Bazin's lineage: when approached from the perspective of total cinema, its emergence today appears not as a break but potentially in line with the evolution and emancipation of film as an art form. 3-D already altered traditional film language; yet VR is here to radically overthrow canonical concepts in film practice and theory. Whenever it is addressed in contemporary film scholarship, VR is often met with considerable suspicion: as an immersive medium, it would be unfit for linear storytelling, and the viewing experience is asocial - in any case, the opposite of what one would expect in ciné-clubs or cinématheques. Furthermore, VR is associated with reprehensive practices, like gambling, pornography and addictive gaming, ${ }^{116}$ discrediting its use in a variety of pedagogical and therapeutic experiments (the so-called 'empathy device'), as well as its cinematographic potential. Once again, a side of the critical discourse seems to take on René Barjavel's sarcastic punch: 'Cut off his tongue!'117

And indeed, Virtual Reality is here to change film language at its core: what is montage, a shot-reverse-shot or a close-up in VR? What is on- and off-screen, when the screen is all-around? These major concerns for contemporary media development resonate with Bazin's realist perspective: to move from 'showing' to 'signifying' in VR demands an entirely new semantic. Is Bazin in 1953, for example, thinking of Virtual Reality, when he writes:

Should we then imagine a truly expandable screen that would bring us back around to the use of the iris to concentrate on a single point of the scene $[. .$.$] ? There are so many hypotheses, the choice among which is worth$ leaving to the impending history of cinema. It won't be much longer. ${ }^{118}$

While Bazin saw color, sound and $3-\mathrm{D}$ as unavoidable steps towards increased realism in film, others before him deemed the invention of color too popular, reminiscent of tabloid magazines. From this perspective, film scholar Rudolf

115 Bazin, 1949a, EC p. $5^{18 .}$

116 See Dixon, Wheeler Winston. 'Slaves of Vision: The Virtual Reality World of Oculus Rift.'

Quarterly Review of Film and Video, Vol.33, No.6 (2016): pp. 501-510.

117 Barjavel, 1944, p. 22.

118 Bazin, 1953a, EC p. 1164; Transl. Andrew, 2014, p. 247. 
Arnheim rejects realism in his 1933 book Film as Art, citing a rather pedantic critic by the name of $\mathrm{H}$. Baer:

Uncivilized man is not as a rule satisfied with black-and-white. Children, peasants and primitive peoples demand the highest degree of bright colouring. It is the primitives of the great cities who congregate before the film screen. Therefore, film calls in the aid of bright colours. It is a fresh stimulus. ${ }^{119}$

For similar reasons, extensively discussed in the first chapter of this book, sound, too, introduced a so-called degraded realism. Yet as the title of Arnheim's book illustrates, the stringency of his theories goes hand in hand with the defence of film as a worthy art form. Touching upon the expansion of cinema screens in the fifties, Arnheim again argues for film art by deliberately dismissing realism:

The temptation to increase the size of the screen goes with the desire for coloured, stereoscopic, and sound film. It is the wish of people who do not know that artistic effect is bound up with the limitations of the medium and who want quantity rather than quality. They want to keep on getting nearer to nature and do not realize that they thereby make it increasingly difficult for film to be art. ${ }^{120}$

Arnheim rejects precisely that which Bazin groups under 'total cinema': the 'complete film', in Arnheim's terminology, is 'the mechanical imitation of nature to an extreme.' ${ }^{121}$ Yet, even the most uppish critic today will not dare to doubt the added value of color and sound: think of Alfred Hitchcock, who emphasizes the psychological developments of his characters in Vertigo with color - or Chaplin, literally stumbling over his words in Modern Times (which, then again, hits the core of his comedy). No matter how heartfelt his comments were, the reality is that to this day the history of film has evolved towards an ever-shrinking gap between image and reality - precisely this gap from which today Virtual Reality is emerging.

Unlike Arnheim's complete film, Bazin's total cinema embraces the fact that film techniques continue to extend beyond the borders of the screen.

119 H. Baer cited in Arnheim (1933) 'The Complete Film', 1957, p. 159.

120 Arnheim (1933) 'The Making of a Film', 1957, p. 75.

121 Arnheim (1933) 'The Complete Film', 1957, p. 154; similarly, Joubert-Laurencin sees Bazin's realism as a reversal of Arnheim's tradition (2014, p. 47) as does Tom Gunning, 2011, pp. 122-123. 
Tom Gunning, for example, understands total cinema as the 'phenomenological image of the world as bounded by a horizon, and it is in the nature of a horizon to be expanded. ${ }^{122}$ Gunning here refers to a metaphysical frame of reference, yet the expansion in this case is cinematographic as well, as Bazin indirectly frames these 'truly expandable screens', reminiscent of VR, on a continuum with the development of sound aesthetics:

The evolution of cinema since sound, overall and in particular during the past decade, leans to a negation of montage and of plastic aesthetics, at least the sort of pictorial plastics based on the existence and proportions of the frame. [...] Montage itself relies indirectly on the dimensions of the screen, to the extent to which the close-up is conceivable only in a tight frame. ${ }^{123}$

From this citation follows that, given the dependence of montage on the frame, this practice slowly but surely will lose its dominance in film language. The acoustics of off-screen sound already move beyond the edges of the screen; CinemaScope and other panoramic screens incite the spectators to move their heads and choose their own focus point; and depth perception in 3-D, which breaks the surface of the screen more than the frame, is only possible when the spectator makes a mental superimposition of the left and the right image. Yet this 'truly expandable screen' goes further than CinemaScope or 3-D and reminds us of Virtual Reality where, paradoxically enough, the smallest screen is the most immersive.

While editing remains crucial in contemporary film language, Bazin sees with the increase in screen size of the fifties the necessity to at least put its position as the principal signifier in perspective: "[the interest in widescreen] has come along to definitely destroy montage as the key element in cinematic discourse'. ${ }^{124}$ Virtual Reality, too, rejects the 'existence and proportions of the frame', and so editing as we know it becomes problematic. This way, Alejandro G. Iñárritu reasons that 'VR is all that cinema is not, and vice versa; the frame is gone and the two-dimensional limits are dissolved'. ${ }^{25}$ Explaining the difficulties with composing the script for Carney Arena (2017), a 6-minute walk-around VR installation, ${ }^{126}$ Iñárritu links the disappearance of the frame to his own loss of control as a director:

\footnotetext{
122 Gunning, 2011, p. 125.

123 Bazin, 1953a, EC p. 1164; Transl. Andrew, 2014, p. 246.

124 Bazin, 1954a, EC p. 1313; Transl. Andrew, 2014, p. 292.

125 Iñárritu cited in Pomeroy, 2017.

126 Being a walk-around installation, Carne y Arena necessitates virtual imagery (e.g. the use of motion capture technology and CGI), which are in this case strikingly mixed with natural
} 
Film in a way is a bi-dimensional tiny reality that I create in $20 \%$ of your brain that you passively observe. But this is basically the end of the dictatorship of this frame: you go into, you take the space, you own the space. And I do not control: I created $20 \%$, here I create 360 degree of your universe, but you are free to do whatever you want - which is terrifying [...]. Here [in the $20 \%$ frame] it's very easy; honestly to make films is very primitive: I show you that, and you have to imagine the other reality that I don't show you. So, if two guys are in a restaurant talking, you have to imagine the waiters behind. You make your mind here [in your head] but I don't have to show it to you - I just put some sound and that's it. Here, if you turn, I have to put the waiter there. ${ }^{127}$

Essentially, VR exposes an ongoing power play between spectator and director for the simple reason that a frame makes it easier to direct the spectator's gaze: with 'normal' cinema, no one will look for a waiter in the back of a theater. Yet, if the director wants me to find him in VR, he may in fact use techniques that will most likely make me turn my head. In Carne y Arena, for example, 'off-screen' sound is used to navigate this extreme centrifugal screen: after a more-or-less uniform soundscape of immigrants talking sporadically as they continue their journey, the deafening sound of a helicopter hovering over the Mexican desert demands everyone's attention, and its blinding searchlight then enables an otherwise not-so-subtle cut to a different shot. This is what Jessica Brillhart, in-house VR filmmaker at Google, calls 'probabilistic experiential editing': 'understanding a visitor's likely interaction with the world around them'. ${ }^{128}$ Rather than completely giving up control, VR-makers need to guide spectators with cues towards so-called 'points of interest' in the scene; shot transitions work best when they abide by 'match on attention'; and pre-production decoupage is complemented with post-production 'stitching'. ${ }^{129}$ In other words, it appears as though VR recreates the most basic spectacle, everyday perception: as in

elements, like the coldness of the detention center waiting room, the desert sand on your bare feet or wind blowing in your face.

127 Iñárritu, 2018

128 Brillhart, 2016; Brillhart frames her lecture around four crucial aspects concerning VR:

'1. Wait, what happened to my frame?

2. Editing doesn't work. Oh wait, it does? I'm confused.

3. THE CAMERAS ARE MADE OUT OF PEOPLE?!

4. What about storytelling?'

From there on, she discusses her own approach to VR editing, narrative structure and identification.

129 See: Brillhart, 2015-2016. 
reality, on an infinite screen each detail or object may potentially become meaningful, provided that we pay attention to it.

This grammar of VR is destined to develop itself by wavering on the ever-shrinking gap between image and reality: a balancing act which, in any case, will not follow the logic and dimensions of the frame, i.e. editing, but necessarily seek more realist semantics. Dudley Andrew describes these semantics as initiating 'one powerful line of French theory which treats film as an art which "discovers" significance rather than "constructs" meaning,, ${ }^{130}$ and he identifies Bazin as the initiator of this 'Cahiers du cinéma line of thought, applied to questions of editing'. ${ }^{131}$ Bazin's notorious stance against editing, then, is tied to his views on the evolution of film language, which offers spectators an aesthetic to discover. 'They are no longer tethered like Plato's slaves,' Andrew writes, 'staring straight ahead "On Screen, in Frame". ${ }^{132}$ In the article to which Andrew refers here, 'On Screen, in Frame: Film and Ideology' (1976), Stephen Heath attacks the 'cinematic practice in favour of a transparent presentation of "reality" (cinema - "the art of the real"),', ${ }^{133}$ specifically targeting Bazin's centrifugal screen. ${ }^{134}$ Instead, emphasizing his semiotic position, Heath writes: 'the stake of the frame is clear [...]: the frame is the reconstitution of the scene of the signifier, of the symbolic, into that of the signified.'135 Keeping in mind that editing depends on the proportions of the frame, Bazin's centrifugal screen (which rejects the frame) inevitable leads to a different semantic process. In his own words, by rejecting the frame, wide-screen cinema 'approaches its deep vocation, which is to show even before expressing, or more precisely, to express by evidence of the real, which is to say once again: not by signifying but by revealing'. ${ }^{136}$

Discovery rather than construction, then, not only typifies post-war film aesthetics but returns today in a seemingly contradictory form. The point, however, is not to prove that Bazin knew this all along, or even that the future masterpieces will be made in VR. Instead, my purpose was to show, with Bazin, that what cinema is has been characterized by trial and error, starting with the supposedly detrimental effect of sound film on silent film theory, followed by the debate over 3-D film and now VR. If construction implies a pre-conceived plan or essence that gradually takes form, discovery

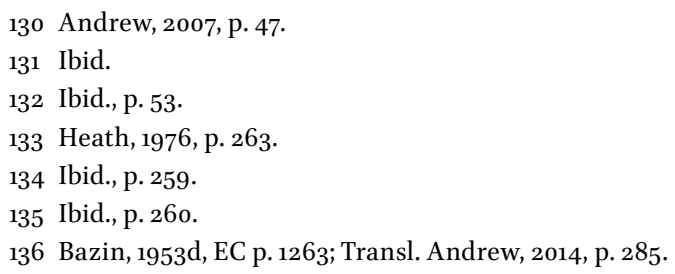




\section{leaves the development of film theory open for possibilities not previously part of the plan: not yet invented.}

\section{Bibliography}

Almendros, Nestor (1990). Días de una cámara. Madrid: Seix Barral.

Andrew, Dudley (1995). Mists of Regret: Culture and Sensibility in Classic French Film. Princeton: Princeton University Press.

--- (2007). 'A Film Aesthetic to Discover.' Cinémas:Journal of Film Studies, Vol. 17, No. 2-3: pp. 47-71.

--- (2011). 'Malraux, Bazin, and the Gesture of Picasso.' In: Opening Bazin: Postwar Film Theory and Its Aftermath. Eds. Dudley Andrew and Hervé Joubert-Laurencin. New York: Oxford University Press, pp. 153-166.

--- (2013). André Bazin. New York: Oxford University Press.

Archimedes. 'On Floating Bodies. Book I.' The Works of Archimedes. Ed. T.L. Heath. Cambridge: Cambridge University Press (1897): pp. 253-262.

Arnheim, Rudolf (1957). Film as Art. Berkeley: University of California Press.

Austin, Guy (1996). Contemporary French Cinema: An Introduction. Manchester: Manchester University Press.

Austin, L.J. (1953). 'La Genèse du “Cimetière marin”.' Cahiers de l'association internationale des études françaises, No. 3-5: pp. 253-269.

Barjavel, René. Cinéma total: essai sur les formes futurs du cinéma. Paris: Éditions Denoël (1944)

Barthes, Roland (1957). 'Operation Margarine.' Mythologies. Transl. Annette Lavers. New York: Hill \& Wang (1972): pp. 41-42.

Baudelaire, Charles (1861). 'Le Voyage.' Les Fleurs du mal. Paris: Poulet-Malassis et De Broise, pp. 305-313.

Bazin, André (1943b). 'Pour une esthétique réaliste.' L'Information universitaire, No. 1168 (6 November). EC I, 5 .

--- (1945). 'Ontologie de l'image photographique.' Qu'est-ce que le cinéma? Paris: Éditions du Cerf (2008): pp. 9-18. EC OP, 1.

--- (1946/1958). 'Le Mythe du cinéma total.' Qu'est-ce que le cinéma? Paris: Éditions du Cerf (2008): pp. 19-24. EC OP I, 2.

--- (1949a). 'Misère, servitude et grandeur de la critique de films.' Revue internationale du cinéma, No. 2 (April). EC VII, 572.

--- (1950-1955). 'L'Évolution du langage cinématographique.' Qu'est-ce que le cinéma? Paris: Éditions du Cerf (2008): pp. 63-8o. EC OP, 17.

--- (1950b). 'La "technique" et le "sujet" ne jouent pas au cinéma le même rôle que dans les autres arts: la forme et le fond.' Radio cinéma télévision, No. 45 (28 November). EC VIII, 771.

--- (1951c). 'Théâtre et cinéma.' Qu'est-ce que le cinéma? Paris: Éditions du Cerf(2008): pp. 129-178. EC IX, $797 \& 817$.

--- (1951e). 'De la forme et du fond ou la “crise” du cinéma.' Almanach du théâtre et du cinéma. EC VIII, 774 .

--- (1952c). 'Un nouveau stade du cinéma en relief: le relief en équations.' Radio cinéma télévision, No. 131 (20 July). EC X, 1087.

--- (1953a). 'La guerre de trois dimensions, aura-t-elle lieu?' L'Observateur No. 153 (2 April). EC XIII, 1305 .

--- (1953c). 'CinemaScope e neo-realismo.' Filmcritica, No. 28 (September). EC XIV, 1407. 
---(1953d). 'Le CinémaScope sauvera-t-il le cinéma?' Ésprit, No. 207-208 (10 November-December). EC XIV, 1430.

--- (1953e). 'Le langage de notre temps.' In: Regards neufs sur le cinéma. Eds. Jacques Chevallier and Max Egly. Paris: Éditions du Seuil (1963): pp. 5-17. EC XII, 1202.

--- (1954a). 'Le Cinémascope. Fin du montage.' Cahiers du cinéma, No. 31 (January). EC XIV, 1497.

--- (1956a). 'Le petit journal du cinema: Un préjugé qui me coûtait cher.' Cahiers du cinema, No. 62 (August). EC XIX, 2111.

--- (1956b). 'Le Monde du silence: Icare sous-marin.' Radio cinéma télévision, No. 319 (26 February). EC XIX, 1993.

--- (1956c). 'Le Monde du silence.' France observateur, No. 303 (1 March). EC XIX, 1997.

--- (1957b). 'De la politique des auteurs.' Cahiers du cinéma, No. 70 (April). EC XXI, 2275.

--- and Jean-Pierre Chartier (1942). 'Peut-on s'intéresser au cinéma?' Maison des lettres (December). EC I, 1.

--- and Georges Sadoul (1945-1949). 'Convergences et divergences sur la profondeur de champ et le sujet.' 1895: Revue d'histoire du cinéma, No. 67 (Summer 2012): pp. 126-143.

Chartier, Roger (2003). Dictionnaire encyclopédique du Livre. Tome I. Paris: Cercle de la Librairie.

Daney, Serge (1991). 'The Demise of Critical Thinking.' Transl. Stoffel Debuysere. Diagonal Thoughts. [Accessed 30/10/2017] <http://www.diagonalthoughts.com/? $\mathrm{p}=15^{21}>$.

--- (1993). L'exercice a été profitable, Monsieur. Eds. Jean-Claude Biette and Emmanuel Crimail. Paris: P.O.L.

Darke, Chris (1993). 'Rupture, continuity and diversification: Cahiers du cinéma in the 1980s.' Screen, Vol. 34, No. 4 (December): pp. 362-379.

Dixon, Wheeler Winston (2016). 'Slaves of Vision: The Virtual Reality World of Oculus Rift.' Quarterly Review of Film and Video, Vol. 33, No. 6: pp. 501-510.

Eisenstein, Sergei (1947). 'On Stereocinema.' In: ${ }_{3} D$ Cinema and Beyond. Eds. Dan Adler, Janine Marchessault and Sanja Obradovic. Toronto: Public 47 (2013): pp. 20-59.

Elsaesser, Thomas (2013). "The "Return" of 3-D: On Some of the Logics and Genealogies of the Image in the Twenty-First Century.' Critical Inquiry, Vol. 39 (Winter): pp. 217-246.

Gunning, Tom (2004). 'An Aesthetic of Astonishment: Early Film and the (In)credulous Spectator.' In: Film Theory: Critical Concepts in Media and Culture Studies. Volume 3. Eds. Philip Simpson, Andrew Utterson and K.J. Shepherdson. New York: Routledge, pp. 78-95.

--- (2011). 'The World In Its Own Image: The Myth of Total Cinema.' In: Opening Bazin: Postwar Film Theory and Its Aftermath. Eds. Dudley Andrew and Hervé Joubert-Laurencin. New York: Oxford University Press, pp. 119-126.

Harries, Karsten (2002). Infinity and Perspective. Cambridge: The MIT Press.

Heath, Stephen (1976). 'On Screen, In Frame: Film and Ideology.' Quarterly Review of Film Studies, Vol. 1, No. 3: pp. 251-265.

Joubert-Laurencin, Hervé (2014). Le Sommeil paradoxal: écrits sur André Bazin. Montreuil: Les Éditions de l'œil.

Loiperdinger, Martin (2004). 'Lumière's Arrival of the Train: Cinema's Founding Myth.' The Moving Image, Vol. 4, No. 1 (Spring): pp. 89-118.

Lumière, Louis (1936). 'Stereoscopy On the Screen.' Journal of the Society of Motion Picture Engineers, Vol. 27, No. 3 (September): pp. 315-320.

Merleau-Ponty, Maurice (1945). 'Cézanne's Doubt.' In: Sense and Non-Sense. Illinois: Northwestern University Press (1964): pp. 9-25.

Perec, Georges (1978). Les Choses communes:Je me souviens. Paris: Hachette.

Ross, Miriam (2015). ${ }_{3}$ D Cinema: Optical Illusion and Tactile Experiences. New York: Palgrave Macmillan. 
Sadoul, Georges (1948). 'La Métaphysique de la profondeur de champ.' 1895: Revue d'histoire du cinéma, No. 67 (Summer 2012): pp. 132-137.

Truffaut, François (1983). 'André Bazin nous manque.' Le Plaisir des yeux. Paris: Flammarion (2014): pp. 54-63.

Valéry, Paul (1920). 'Le Cimetière marin.' Charmes. Paris: Gallimard (1952): pp. 222-241.

Wagner, Jon (1988). 'Lost Aura: Benjamin, Bazin and the Realist Paradox.' Spectator, Vol. 1 (Fall): pp. 57-69.

Wenders, Wim and Mary Zournazi (2013a). Inventing Peace: A Dialogue on Perception. London: I.B. Tauris.

Wenders, Wim (2013b). 'A Film for Pina: Keynote of the Toronto International Stereoscopic $3 \mathrm{D}$ Conference.' In: ${ }_{3}$ D Cinema and Beyond. Eds. Dan Adler, Janine Marchessault and Sanja Obradovic. Toronto: Public 47, pp. 214-233.

Zone, Ray (2005). 'A Note on “Cinema's Founding Myth”.' The Moving Image, Vol. 5, No. 2 (Fall): pp. 146-147.

--- (2007). Stereoscopic Cinema and the Origins of 3-D Film, 1838-1952. Lexington: The University of Kentucky Press.

--- (2012).3-D Revolution: The History of Modern Stereoscopic Cinema. Lexington: The University of Kentucky Press.

\section{Other sources}

'Tout le mal que "Le Grand Bleu” a fait à l'apnee.' 20 minutes, 02/o6/2016. [Accessed 30/10/2017] <http://www.2ominutes.fr/marseille/1857651-2016o6o2-tout-mal-grand-bleu-fait-apnee>.

Bordwell, David (2019). 'Adieu au langage: $2+2 x_{3}$ D.' Observations on Film Art (7 September). [Accessed 25/04/2019] <http://www.davidbordwell.net/blog/2014/o9/o7/ adieu-au-langage-2-2-x-3d/>.

Brillhart, Jessica (2015-2016). 'The Language of VR.' Medium.com. [Accessed 25/04/2019] <https:// medium.com/the-language-of-vr>.

--- (2016). 'VR \& Cinema - Google I/O 2016.' Google Developers (19 May). [Accessed 25/04/2019] <https://www.technologyreview.com/lists/innovators-under-35/2017/pioneer/ jessica-brillhart/>.

Dallas, Paul (2014). '1+1=3.' Filmcomment (November/December). [Accessed 25/04/2019] <http:// www.filmcomment.com/article/fabrice-aragno-interview $>$.

Ebert, Roger (2010). 'Why I Hate 3D.' Newsweek (5 October). [Accessed 25/04/2019] < http://www. newsweek.com/roger-ebert-why-i-hate-3d-movies-70247>.

Frazer, Bryant (2014). 'Five Ways Jean-Luc Godard Breaks the 3D Rules in Farewell to Language.' StudioDaily (3 October). [Accessed 25/04/2019] <http://www.studiodaily.com/2014/10/ five-ways-jean-luc-godard-breaks-the-3d-rules-in-farewell-to-language/>.

Iñárritu, Alejandro G. \& Jenna Pirog (2018). 'Carne y Arena: Art and Technology.' The Philips Collection. 4June. [Accessed 25/04/2019] <https://www.youtube.com/watch?v=-XcvJ6lUTwI $>$.

Legato, Rob. 'Hugo and the Joy of Filmmaking.' CreativeCOW.net [Accessed 21/02/2015] < https:// library.creativecow.net/legato_rob/magazine_3o_HUGO/1>.

Lodge, Guy (2015). 'Every Thing Will Be Fine.' Variety (10 February). [Accessed 25/04/2019] <http:// variety.com/2015/film/reviews/berlin-film-review-every-thing-will-be-fine-1201429546/>.

Marsh, Calum (2014). 'The Shot of the Year.' The Dissolve (19 December). [Accessed 25/04/2019] <https://thedissolve.com/features/2014-in-review/866-the-shot-of-the-year/>. 
Pagliano, Jean-Pierre (1988). 'Profils perdus: André Bazin.' France culture (2o October). [Accessed 25/04/2019] <https://podcloud.fr/podcast/les-nuits-de-france-culture/episode/profils-perdusandre-bazin-2eme-partie-1ere-diffusion-27-slash-10-slash-1988 > [Radio program].

Pattinson, Michael (2015). 'Wim Wenders' Every Thing Will Be Fine is a Major Disappointment.' Indiewire (10 February). [Accessed 25/04/2019] <http://www.indiewire.com/article/ berlin-review-wim-wenders-every-thing-will-be-fine-is-a-major-disappointment-20150210>.

Pomeroy, Robin (2017). 'Iñárritu Puts a Boarder Guard's Gun to Your Head in VR Film at Cannes.' Reuters, (22 May). [Accessed 25/04/2019] <https://www.reuters.com/article/ us-filmfestival-cannes-inarritu-idUSKBN18I2C $>$.

Roxborough, Scott (2014). 'Wim Wenders on How 3 D Is Drowning "In a Lack of Imagination" (Q\&A).' The Hollywood Reporter (2 May). [Accessed 25/04/2019] <http://www.hollywoodreporter.com/news/berlin-wim-wenders-how-3d-677303>.

Stereographics Developers' Handbook (1997). Stereographics Corporation. [Accessed 25/04/2019] <http://www.cs.unc.edu/Research/stc/FAQs/Stereo/stereo-handbook.pdf>.

Wenders, Wim (2015). 'Every Thing Will Be Fine | Press Conference Highlights | Berlinale 2015.' YouTube (10 February). [Accessed 25/04/2019] <https://www.youtube.com/ watch? $\mathrm{v}=6 \mathrm{yI} 7 \mathrm{Coegzy} 8 \# \mathrm{t}=45>$.

--- (2015). 'Every Thing Will Be Fine: An Interview with Director Wim Wenders.' The Upcoming (10 February). [Accessed 25/04/2019] <http://www.theupcoming.co.uk/2015/02/10/ every-thing-will-be-fine-an-interview-with-director-wim-wenders/>.

\section{Used translations}

Daney, Serge (1991). 'The Demise of Critical Thinking.' Transl. Stoffel Debuysere. Diagonal Thoughts. [Accessed 30/10/2017] <http://www.diagonalthoughts.com/?p=1521>.

Baudelaire, Charles (1993). 'The Voyage.' In: The Flowers of Evil. Transl. James McGowan. Oxford: Oxford University Press.

Bazin, André. 'On the Politique des auteurs.' Transl. Peter Graham. In: Cahiers du cinéma: The 1950s Neo-Realism, Hollywood, New Wave. Vol. ı. Ed. Jim Hillier. Oxon: Routledge (2005): pp. 248-259.

---. What Is Cinema? Transl. Timothy Barnard. Montreal: Caboose (2009).

---. Bazin On Global Cinema, 1948-1959. Transl. Bert Cardullo. Texas: University of Texas Press (2014).

---. André Bazin's New Media. Transl. Dudley Andrew. Berkeley: University of California Press (2014).

\section{Filmography}

L'Entrée d'un train en gare à La Ciotat (Auguste \& Louis Lumière, 1896)

L'Entrée d'un train en gare à La Ciotat $3 D$ (Louis Lumière, 1903)

The Wheel (Abel Gance, 1923)

The Human Beast [La Bête humaine] (Jean Renoir, 1938)

Around Is Around (Norman McLaren, 1952)

Now Is the Time (Norman McLaren, 1952)

The Graduate (Mike Nichols, 1967) 
The Swimmer (Frank Perry, 1968)

Deep End (Jerry Skolimowski, 1970)

The Big Blue [Le Grand Bleu] (Luc Besson, 1988)

Red Wood Pigeon [Palombella rossa] (Nanni Moretti, 1988)

Titanic ${ }_{3} D$ (James Cameron, 1996)

Swimming Pool (François Ozon, 2003)

Welcome (Philippe Lioret, 2009)

Hugo (Martin Scorsese, 2011)

Pina (Wim Wenders, 2011)

Les Trois Désastres (Jean-Luc Godard, 2013)

The Wind Rises (Hayao Miyazaki, 2013)

Adieu au langage (Jean-Luc Godard, 2014)

Cathedrals of Culture (Wim Wenders, 2014)

Every Thing Will Be Fine (Wim Wenders, 2015)

The Beautiful Days of Aranjuez (Wim Wenders, 2016)

Submergence (Wim Wenders, 2017)

Carne y Arena (Alejandro G. Iñárritu, 2017)

\section{Illustrations}

Figure 29. Astra margarine advertisement, 'Astra rend tout meilleur: recette du beefsteak au poivre' (1952)

Figure 30-32. Diagram on parallax degrees from 'Math Equations for $3^{D}$ ' (A. Bazin, 1952), included in Dudley Andrew's André Bazin's New Media (2014): pp. 237-240 
